NBER WORKING PAPER SERIES

\title{
THE WAGE STRUCTURE AND THE SORTING OF WORKERS INTO THE PUBLIC SECTOR
}

\author{
George J. Borjas \\ Working Paper 9313 \\ http://www.nber.org/papers/w9313
NATIONAL BUREAU OF ECONOMIC RESEARCH 1050 Massachusetts Avenue
Cambridge, MA 02138
October 2002

The views expressed herein are those of the authors and not necessarily those of the National Bureau of Economic Research.

(C) 2002 by George J. Borjas. All rights reserved. Short sections of text, not to exceed two paragraphs, may be quoted without explicit permission provided that full credit, including (C) notice, is given to the source. 
The Wage Structure and the Sorting of Workers into the Public Sector

NBER Working Paper No. 9313

October 2002

JEL No. J3, J4

\begin{abstract}
This paper uses data from the U.S. Decennial Census and the Current Population Surveys to document the differential shifts that occurred in the wage structures of the public and privatesectors between 1960 and 2000. The wage gap between the typical public sector worker and a comparable private sector worker was relatively constant for men during this period, but declined substantially for women. Equally important, wage dispersion in the public sector was increasing relative to wage dispersion in the private sector prior to 1970, at the time when public sector employment was rising rapidly. Since 1970, however, there has been a significant relative compression of the wage distribution in the public sector. The different evolutions of the wage structures in the two sectors are an important determinant of the sorting of workers across sectors. As a result of the relative wage compression, the public sector found it increasingly more difficult to attract and retain high-skill workers
\end{abstract}

George J. Borjas

Kennedy School of Government

Harvard University

79 JFK Street

Cambridge, MA 02138

and NBER

gborjas@harvard.edu 


\section{THE WAGE STRUCTURE AND THE SORTING OF WORKERS INTO THE PUBLIC SECTOR}

\section{George J. Borjas*}

The public sector employs around 16 percent of the American workforce. Since the 1970s, there has been a flurry of research activity attempting to document and understand the pay practices of that sector. Smith (1977), for instance, began a voluminous empirical literature that examines if public sector workers receive "equal pay for equal work" when compared to their private sector counterparts (see also Gyourko and Tracy, 1988; Moulton, 1990; and Katz and Krueger, 1991). ${ }^{1}$

The last two decades have also witnessed a remarkable change in the U.S. wage structure. In particular, there has been a substantial increase in wage inequality among salaried workers, both between and within skill groups. ${ }^{2}$ There is little disagreement that such an increase occurred. There is still a debate, however, over the factors that may have caused the widening of the wage distribution. ${ }^{3}$ The "list of usual suspects" includes the de-unionization of the U.S. labor market, the increased globalization of the economy, the resurgence of immigration, and skillbiased technological change.

* Robert W. Scrivner Professor of Economics and Social Policy, John F. Kennedy School of Government, Harvard University; and Research Associate, National Bureau of Economic Research.

1 There have also been many studies that analyze various aspects of the labor market in the public sector, such as the interplay between political factors and market forces in setting public sector pay (Borjas, 1980, 1984; Craig, 1995); employment discrimination and comparable worth remedies (Borjas, 1982; Hundley, 1993); the determination of job queues and quit rates (Black, Moffitt, and Warner, 1990; Ippolito, 1987; Krueger, 1988); and wage-setting in particular local governments or federal agencies (Moore and Newman, 1991; Perloff and Wachter, 1984). Ehrenberg and Schwarz (1986) and Gregory and Borland (1999) provide detailed surveys of this literature.

2 Juhn, Murphy, and Pierce (1993), Katz and Murphy (1992), and Murphy and Welch (1992) document these important trends.

3 Studies identifying some of the factors responsible for the changes in the wage structure include Bound and Johnson (1992), Freeman (1993), and Autor, Katz, and Krueger (1998). Katz and Autor (1999) present a detailed survey of the literature. 
Although much of the focus in the debate over the public sector wage structure has emphasized the size of the pay differential between the typical worker employed in the public sector and a statistically comparable counterpart in the private sector, this emphasis is somewhat myopic. Given the remarkable changes in the wage structure that occurred over the past 20 years, it is unlikely that the wage structure evolved in similar ways in the private and public sectors. As a result, there could be sizable differences in the trend of the public-private sector pay gap for workers in different skill groups.

Differential changes in the wage structure between the public and private sectors can be reasonably expected to alter the behavior of many economic agents. Suppose (as is actually the case) that wage dispersion has been rising at a faster rate in private sector jobs than in public sector jobs. The relative change in the wage structure would then suggest that private sector workers who belong to highly skilled groups (such as college graduates), or private sector workers who have relatively high earnings within a particular skill group, will have reduced incentives to enter the public sector. Conversely, public sector workers who belong to highly skilled groups, or public sector workers who have relatively high incomes within a particular skill group, will have increased incentives to leave the public sector and enter private sector jobs. In short, the relative changes in the wage structure should influence labor supply decisions, and alter the sorting of workers between the two sectors.

This paper uses data drawn from the U.S. decennial Censuses and from the Current Population Surveys (CPS) to document the changes in the wage structure that occurred in the private and public sectors between 1960 and $2000 .{ }^{4}$ The evidence suggests that relative wage

\footnotetext{
${ }^{4}$ The paper is closely related to the analysis of Katz and Krueger (1991), who also use CPS data between 1967 and 1987 to estimate both the size of the pay gap between public and private sector workers, as well as to provide some evidence on the different evolutions of the wage structure in the two sectors. The present paper updates many of the Katz-Krueger calculations through the year 2000, as well as extends the analysis by
} 
inequality was actually rising in the public sector prior to 1970, but that there has been substantial relative wage compression in that sector since the 1970s. The paper also examines if the different evolution of the wage structure in the two sectors altered the behavioral decision of how workers allocate themselves between the sectors. The empirical analysis suggests that as a result of the relative compression of public-sector wages since 1970, high-skill private sector workers became increasingly less likely to quit their jobs to enter the public sector, and high-skill public sector workers became increasingly more likely to switch to the private sector.

\section{Trends in Employment and Pay Levels}

It is instructive to begin the discussion by describing some general trends in public sector employment and pay over the past few decades. I will use two main sources of data throughout much of the study: a 1 percent sample drawn from the Public Use Microdata Samples (PUMS) of the U.S. Census for the years 1960 through 1990; and the Annual Demographic Supplement (i.e., the March Supplement) of the Current Population Surveys for the years 1977 through 2001.

I restrict the analysis to workers who are between 18 and 64 years old and are not selfemployed. A particular worker is classified as employed in the private or public sectors based on the information provided in the "class of work" variable in these data sets. This variable indicates if the worker is employed in the public or private sector. Beginning with the 1970 Census, the class of work variable also indicates if a public sector worker is employed by the federal, state, or local governments.

investigating the link between the skills of workers who move across sectors and the relative changes in the wage structures. 


\section{Employment}

Figure 1 illustrates the trend in the fraction of the workforce that is employed by the public sector over the $1960-2000$ period. ${ }^{5}$ Although the time-series presented in the figure use data drawn from two different sources (i.e., the Census and the CPS), it is worth noting that the levels of public sector employment in the two data sets match quite well. In 1960, the public sector employed around 15 percent of the workforce. The size of the public sector-in terms of relative employment - peaked in the mid-1970s, when nearly 20 percent of workers were employed by the public sector. Since then, the share of public sector employment has declined steadily; by 2000, the share had declined to around 16 percent.

Figure 1 also shows that much of the post-1980 decline in public sector employment can be attributed to what has been happening in the local government sector. The (relative) number of persons employed by local governments fell substantially in the past two decades. In 1976, about 11 percent of workers were employed by local governments. By 2000, only 8 percent of workers were employed by local governments. In contrast, the employment share of both state government and the federal government remained steady at around 4 percent through this period.

Figure 2 summarizes the trends in public sector employment for male and female workers. Although women are much more likely to be employed in the public sector, the trends in employment shares are quite similar for the two groups. For both men and women, the share of public sector employment peaked in the mid-1970s, at around 17 percent for men and 22 percent for women. By 2000, only 14 percent of men and 19 percent of women were public

\footnotetext{
5 In both Census and CPS data, much of the employment information, such as earnings, refers to the calendar year prior to the survey. I typically use this timing convention when presenting the data throughout the paper. The exception is the presentation of the 1960 Census data. For expositional convenience, the figures date this data point as of 1960 (when, in fact, it refers to 1959).
} 
sector employees, and much of the decline in employment for both men and women can be attributed to the contracting size of the local government sector.

\section{The public sector pay gap}

Many studies calculate the pay gap between comparable workers in the public and private sectors, and examine variations in this pay gap over time and across the various levels of government. In this section, I update this large literature by documenting the long-run trends in the pay gap between 1960 and 2000 .

To calculate the wage differential between public and private sector workers, I use the sample restrictions typically used in the studies that document the evolution of the wage structure in the wage-and-salary sector (Katz and Autor, 1999). In particular, I restrict the analysis to the sample to full-time workers (persons who worked at least 40 weeks per year and 35 hours per week in the calendar year prior to the survey). In addition, I restrict the sample to those full-time workers who earned at least $\$ 67$ per week in 1982 dollars (implying that their hourly income was at least half of the 1982 real minimum wage). Throughout the analysis, I will use the log of weekly wages as the dependent variable. Because there is a substantial wage differential between men and women — both in the public and private sectors - I will estimate the public sector pay gap separately for each gender. Initially, I focus on measuring the pay gap between the (aggregate) public and private sectors. I will discuss the pay differences that exist among the federal, state, and local government sectors below.

The top panel of Figure 3 illustrates the trend in the (unadjusted) log wage differential between the typical male public sector worker and the typical male private sector worker. It is evident that the wage advantage enjoyed by men employed in the public sector rose steadily over 
the past four decades. In 1960, the typical man employed in the public sector workers earned, on average, about the same as the typical man employed in the private sector. The wage premium rose to around 5 percent by 1980 , to 10 percent by 1990 , and peaked at around 13 percent in 1995.

Of course, the increasing pay advantage enjoyed by men working in the public sector may be attributed to differential changes in the human capital of the workers employed in the two sectors. It is important, therefore, to document the trend in the adjusted pay gap, the pay gap that exists between comparable workers employed in public and private sectors.

I used a standard log wage regression to calculate the adjusted pay gap, where the regression controls for differences in educational attainment, age, race, and region of residence. ${ }^{6}$ These regression models were estimated separately in each year, in each sector, and for each gender group. I then used the average characteristics of workers employed in the public sector over the entire 1976-2000 period (by gender) to predict the wage that this worker would have earned if he were employed in a particular sector in a particular year. The adjusted pay gap is obtained by taking the appropriate differences of these predictions.

As the top panel of Figure 3 shows, the calculation of the pay differential between the typical man employed in the public sector and his statistically comparable counterpart in the private sector reveals two interesting findings. First, the typical public sector worker has not, in fact, enjoyed a wage advantage over his statistically comparable counterpart in the private sector. In 2000 , for instance, the typical public sector worker earned 11 percent more than the typical private sector worker. But the typical public sector worker earned 6 percent less than a

\footnotetext{
${ }^{6}$ The independent variables include a vector of dummy variables indicating the worker's age (18-24, 25 34, 35-44, 45-54, and 55-64), educational attainment (less than high school, high school, some college, and a college degree or more), region of residence (Northeast, North Central, South, or West), and a dummy variable indicating if the worker is black.
} 
statistically comparable worker in the private sector. Second, there has been remarkably little change in the adjusted pay gap between 1960 and 2000. In particular, the adjusted pay gap has hovered between -5 and -10 percent throughout much of the past four decades. In short, once one adjusts for differences in socioeconomic characteristics between the workers in the two sectors, the apparent increase in the pay gap between public sector and private sector workers vanishes, and one finds that the relative pay of men in the public sector has remained relatively constant over time.

It turns out that the trends in educational attainment of workers in the two sectors help reconcile the twin findings of a positive and rising unadjusted pay gap and a negative and constant adjusted pay gap. As Table 1 shows, not only are public sector workers, on average, more educated than private sector workers, but this gap seems to be increasing over time. Consider, for example, the extent to which high school dropouts work in each of the sectors. In 1960, 34 percent of the workers in the public sector and 50 percent of the workers in the private sector were high school dropouts. By 2000, there were practically no high school dropouts left among public sector workers, but 11 percent of the private sector workforce was still composed of high school dropouts. At the upper end of the skill distribution, the fraction of private sector workers with at least a college diploma increased by about 17 percentage points, from 8 to 25 percent, between 1960 and 2000, but this fraction rose by 23 percentage points, from 23 to 46 percent, in the public sector.

As the bottom panel of Figure 3 shows, the trends in the adjusted and unadjusted pay gaps are quite different for women. Throughout much of the past four decades, women employed in the public sector have enjoyed a very large wage advantage over women in the private sector-both in terms of the unadjusted and the adjusted pay gaps. In 1960, for example, women 
in the public sector earned around 27 percent more than women in the private sector, and the pay gap remained at 20 percent even after adjusting for differences in socioeconomic characteristics between female workers in the two sectors. By 2000, the unadjusted pay gap had fallen slightly to around 20 percent. However, the monetary advantage suggested by the adjusted pay gap had completely disappeared, so that the typical woman employed in the public sector earned just as much as her statistically comparable counterpart in the private sector. This decline in the pay advantage of women employed in the public sector partly reflects the significant improvement in economic opportunities that private sector female workers experienced over the past few decades.

The two panels of Figure 4 show the different trends in the adjusted pay gap (between the public and private sector) across the various government sectors. It turns out that the aggregate trends illustrated in the previous figures mask a great deal of variation in pay levels among the federal, state, and local government sectors. In particular, Figure 4 shows that, regardless of gender, workers in the federal sector enjoy a significant pay premium over comparable workers in the private sector, while workers employed by state governments suffer a significant wage disadvantage.

For men, the adjusted pay gap between the federal and private sectors declined somewhat, from over 10 percent in the mid-1970s to around 3 percent by 2000 . At the same time, however, men employed in state and local governments experienced some improvement in their pay status. In 1980, these men had wage penalties of around 15 to 20 percent, but the size of the penalty fell to around 10 percent by 2000 .

It turns out that the significant decline in the adjusted wage premium accruing to the typical woman employed in the public sector (and documented in Figure 3) can be attributed to a 
steep drop in wages for women employed by local governments. In 1976, the typical woman employed by a local government earned around 10 percent more than a statistically comparable woman in the private sector. By 2000 , this 10 percent wage advantage had turned into a 10 percent wage disadvantage. It would be of great interest to determine the factors that caused this significant shift in the economic opportunities available to women employed by local governments. After all, it is evident that the factors lowering wages for women in local governments did not affect women employed in other parts of the public sector.

\section{The wage structures in the public and private sectors}

Almost all of the studies that analyze pay differences between the public and private sector attempt to measure the pay gap between the typical worker in the public sector and a statistically comparable worker in the private sector. The magnitude of this pay gap for the typical worker is the focus in most policy discussions of pay comparability between the two sectors.

As I documented in the previous section, the adjusted pay gap between the public and private sectors remained relatively constant for men, but declined substantially for women in the past four decades. However, these trends occurred against a background of historic changes in the U.S. wage structure. In particular, it is well known that wage inequality increased rapidly among wage-and-salary workers in the past two decades - as measured either by a widening of wage differentials across skill groups, or by an increase in wage dispersion within a skill group. For example, the wage differential between college graduates and high school graduates increased throughout much of the 1980s and 1990s. Similarly, the amount of wage inequality 
among narrowly defined education groups also rose substantially. In effect, the labor market began to reward workers with higher levels of skills at much higher rates.

The implications of the trends in the adjusted pay gap for "pay comparability" policy discussions are unclear if the wage structures evolved in different ways in the public and private sectors. In other words, even though the adjusted pay gap for the typical man employed in the public sector may have been relatively constant over a 40 -year period, differential changes in the wage structures imply that the pay gap facing men at different points of the wage distribution could have changed in substantially different ways. For instance, as I will show below, wage inequality increased at a much faster rate in the private sector than in the public sector. This would indicate that high-skill workers would find it increasingly more profitable to work in private sector jobs, making it much increasingly harder for the public sector to attract and retain these high-skill workers. In short, differences in the evolution of the wage structure between the private and public sector - and not simply the magnitude of the adjusted pay gap for the typical worker-have important implications for the number and types of workers that the public sector can successfully recruit and retain.

To describe the secular trends in the wage structures of both private and public sector workers, I again use data drawn from the March Supplements of the CPS for the 1976-2000 calendar years. Although I initially focus on the trends for the aggregate public sector, I will also discuss the separate trends for federal, state, and local government workers in detail below.

A widely used measure of wage dispersion in the wage structure literature is the standard deviation of $\log$ weekly income. Figures 5 and 6 illustrate the trends in this measure of dispersion for men and women, respectively. Consider initially the evidence for male workers. The steep increase in wage dispersion illustrated for male workers employed in the private sector 
is familiar. Between 1960 and 2000, the standard deviation of their log weekly wage rose by almost 40 percent, from about .5 to almost .7—with much of the increase occurring after 1980 . Less familiar is the finding that public sector workers experienced a much slower rate of increase in wage dispersion. In particular, the standard deviation of the log wage for public sector workers increased only from about .4 to .5 between 1960 and 2000, and much of that increase occurred before 1970 - at the time that employment in the public sector was expanding rapidly.

As a result of these trends, the bottom panel of Figure 5 shows that the ratio of standard deviations between the public and private sectors was increasing before 1970, and began to decline thereafter. In 1970, the ratio stood at around .9. By the late 1990s, the ratio had fallen to around .75 . Since a higher rate of return to skills in a particular sector would increase wage inequality in that sector, the ratio of standard deviations between the two sectors can be roughly interpreted as a measure of the relative returns to skills in the public sector. The data clearly indicate that the relative returns to skills for men employed in the public sector have been declining steadily since 1970.

Figure 6 replicates the analysis for female workers. The results are quite similar. In particular, wage dispersion for women employed in the public sector rose-relative to that in the private sector — before 1970, and began to decline steadily after that. In 1970, for example, the ratio of standard deviations stood at around 1.05. By 2000, the ratio was hovering at around .85 .

Although the standard deviation of the log weekly wage is a commonly used measure of wage dispersion, it is a measure that is very sensitive to outlying values in the wage distribution, and particularly to the way that those outlying values are treated in the particular data set being analyzed. The Census and CPS data typically truncate the earnings reported by persons with very high income levels, and instead assign all of these high-income persons a "topcode." For 
example, all persons who earned more than $\$ 75,000$ in the 1980 Census are coded as imply earning $\$ 75,000$. To make matters worse, the truncation point for nominal earnings changes in a haphazard way over time. As a result, the differential topcoding of earnings in different periods can influence the relative trend in the standard deviation of log weekly earnings, particularly if workers in one sector are more likely to be topcoded than workers in another sector. ${ }^{7}$

One can avoid this technical problem by using an alternative measure of wage dispersion, such as the wage gap between the workers at the $90^{\text {th }}$ percentile and the $10^{\text {th }}$ percentile of the wage distribution. This measure of wage dispersion, which I will call the "90-10 wage gap," essentially discards the earnings information for the topcoded observations, and is obviously not sensitive to the technical problems introduced by the topcoding of observations.

The two panels of Figure 7 illustrates the trend in the 90-10 wage gap for workers employed in the public and private sectors. As with the analysis of the standard deviation of log weekly wages, it is clearly evident that wage dispersion in the public sector-relative to that in the private sector-was increasing prior to 1970 , and declined steadily after that. For example, the wage gap between the $90^{\text {th }}$ percentile and the $10^{\text {th }}$ percentile male worker in the private sector was about $1.3 \log$ points in 1980 , and had increased to nearly $1.7 \log$ points by 2000 . In contrast, the 90-10 wage gap in the public sector increased only from about 1.1 to 1.3 over the same period.

It turns out that there was a relative compression of wages in the public sector over the past three decades even when one looks at the evolution of the wage structure within each level of government. To easily summarize the available evidence, I calculated the $90-10$ wage gap in a particular level of the public sector as well as in the private sector, and then took the difference

\footnotetext{
${ }^{7}$ In the 1980 Census, for example, topcoding affects .6 percent of male workers in the private sector, but
} 
between these two quantities to define the relative change in wage dispersion in the public sector. Figure 8 summarizes the evidence by illustrating the trends in the relative 90-10 wage gap for each of the sectors for men and women, respectively. Although the within-sector trends are more "noisy" than the trends found for the aggregate public sector (probably because of the smaller number of observations in the samples of workers in the federal and state governments), the general pattern is unmistakable. For both men and women, it is evident that relative wage dispersion in the public sector declined since the late 1970s. As an example, the 90-10 wage gap for men employed in state government was around -.1 log points smaller than the respective gap for private sector workers in 1980. By 2000, this statistic had fallen to around $-.4 \log$ points, indicating a substantial narrowing of the wage distribution in the state government sector relative to that of the private sector.

It is also of interest to investigate the channels through which wage inequality declined in the public sector relative to the private sector. For instance, it is well known that there was a substantial increase in wage differentials across education groups among wage-and-salary workers. The two panels of Figure 9 show that the increase in educational wage differentials occurred at a much faster rate in the private sector than in the public sector.

In particular, the top panel of Figure 9 shows that there was a substantial rise in the wage gap between male college graduates and high school graduates in the private sector. In 1980, the typical male college graduate in the private sector earned about 40 percent more than the typical high school graduate. By 2000, the wage gap between these two groups had increased to about 66 percent. In contrast, the typical college graduate in the public sector earned 31 percent more than the typical high school graduate in 1980, but this gap had risen to about 49 percent by 2000 . 
The bottom panel of Figure 9 shows a similar widening of educational wage differentials for women in the private sector, and a much smaller widening in the public sector. In fact, the wage gap between college graduates and high school graduates used to be larger in the public sector than in the private sector in 1980. In particular, this educational wage gap was 37 percent in the public sector and 34 percent in the private sector. By 2000, the wage gap between college graduates and high school graduates had risen to 60 percent in the private sector, and to only 53 percent in the public sector. In sum, part of the relative compression of the wage distribution in the public sector can be directly attributed to the fact that the increase in the returns to schooling in public sector jobs did not keep pace with the rise observed in the private sector during the 1980s and 1990s.

Finally, it is also the case that wage inequality in the private sector rose relative to wage inequality in the public sector even within narrowly defined skill groups. I measure within-group wage inequality by the mean-square-error (i.e., the standard deviation of the residual) from a regression of log weekly earnings on age, schooling, region of residence, and race. This regression was estimated separately for each sector, for each gender group, and in each calendar year. Figure 10 illustrates the trend in the ratio of the within-group adjusted standard deviations of the log weekly wage between the public and private sectors. The figure clearly shows that within-group relative inequality was rising in the public sector prior to 1970 , and has fallen steadily since. ${ }^{8}$

In sum, the analysis of the Census and CPS data available since 1960 clearly indicate that there has been a substantial difference in how the wage structures of the public and private

\footnotetext{
${ }^{8}$ To conserve space, I do not show the trends in the educational wage gap or the mean-square-error for the federal, state, and local government sectors separately. Though noisier, the trends within each of the sectors resemble the aggregate trend that indicates a relative compression in government wages both across and within skill groups.
} 
sectors evolved during this period. The much-documented increase in wage inequality, both across and within skill groups, is most evident among private sector workers. Income inequality, either across or within skill groups, did not rise as much in the public sector. Interestingly, this trend was not always the case. Prior to the 1970s, at the time that public sector employment was expanding rapidly, wage inequality was, in fact, rising at a much faster rate in the public sector than in the private sector.

\section{The Sorting of Workers between Sectors}

The fact that relative wages across and within skill groups changed at very different rates in the public and private sectors during the 1980s and 1990s implies that the economic incentives that induce particular types of persons to enter or leave a particular sector also changed over the period. ${ }^{9}$ For instance, suppose the same types of workers tend to do well in both public and private sector jobs - assuming, in effect, that there is a strong positive correlation in potential earnings across the two sectors. Private sector workers who belong to the high-skill groups, or who do quite well within a particular skill groups, should now have fewer incentives to enter public sector jobs. Similarly, public sector workers who belong to the high-skill groups, or who do quite well within a particular skill group, should now have greater incentives to quit their public sector jobs and enter the private sector. In short, the relative compression of wages in the public sector should alter the sorting of workers between the two sectors. Over time, the public sector should find it increasingly more difficult to attract high-skill workers from their current private sector positions, and to prevent high-skill workers from quitting and moving on to the private sector.

\footnotetext{
${ }^{9}$ Blank (1985) presents an early analysis of how workers choose between the public and private sectors.
} 
One can measure how these incentive effects influence the allocation of workers by analyzing the movement of workers between the private and public sectors, and by examining how the skill composition of this flow responded to the relative compression of wages in the public sector. In particular, consider two specific groups of workers. The first group is composed of workers who are initially employed in private sector firms, and who over some time period enter the public sector. The second group is composed of workers who are initially in the public sector, but who decide to leave those jobs and enter the private sector.

Of course, the creation of samples representing these groups of "movers" requires that workers be observed over time, so that we can observe their decision to switch sectors. I conduct the analysis of these in-transit workers by using data drawn from the 1979-2001 CPS Outgoing Rotation Group files (CPS-ORG), which have the key advantage that they provide a much larger sample of workers than the March Supplements of the CPS. ${ }^{10}$ Some of the workers in these files can be matched across two consecutive calendar years. These matched data can be used to determine if the person's class of work (i.e., public or private sector) changed between the twoyear period. As before, I restrict the analysis to wage-and-salary workers aged 18 to 64 .

Table 2 summarizes the transition rates between the various sectors for the entire 19792001 sample period. ${ }^{11}$ During this period, the year-to-year transition rate from the private sector

10 The Current Population Surveys uses a particular type of sample rotation to interview persons. In particular, a chosen household is in the CPS for four months in a row, is then dropped from the sample for 8 months, and is then re-interviewed for four more months. The questionnaire given to the outgoing rotation group (i.e., in the fourth and sixteenth months) contains detailed questions about income and other labor force characteristics. Each annual CPS-ORG file contains about 100,000 working men aged 18-64, so they are significantly larger than the March samples. Due to changes in the survey design, workers cannot be matched between 1984 and 1985, or between 1994 and 1995. For reasons that are not well documented, it is also very difficult to match workers between the 1995 and 1996 surveys. One drawback with the CPS-ORG is that its income data differs from the income data reported in the more commonly used March files. In particular, instead of reporting the annual income in the year prior to the survey, the data reports usual monthly income.

11 The transition rates are calculated in the sample of workers who worked in both years, so that they do not capture transitions in and out of the labor force. 
to the public sector was only 2.5 percent, with most of these movers obtaining a job in the local sector. In contrast, the mobility rate from the public sector to the private sector was 9.7 percent. The transition rate out of the public sector varies significantly across the various levels of government: it was 7.6 percent for federal workers, 11.2 percent for state workers, and 9.7 percent for local government workers. The data also reveal a significant amount of mobility between the state and local sectors, but relatively little movement between the federal sector and other levels of government. In particular, nearly 9.3 percent of state government workers moved to a local government job, and 4.7 percent of local government workers moved to a state job. In contrast, only 1.2 percent of state government workers and 0.7 percent of local government workers moved to a federal job.

For most of what follows, I focus on transitions between the public and private sectors, and ignore those transitions that occur within the public sector itself. Define the quit rate from public sector jobs as the fraction of workers who were initially employed in the public sector, but who became private sector workers in the following year. Similarly, define the entry rate into the public sector as the fraction of workers who were initially in the private sector, and who moved to a public sector job in the following year.

The top panel of Figure 11 illustrates the year-to-year quit rates out of the public sector. It is evident that there was a significant increase in the quit rate out of the public sector beginning around 1990. In the late 1980s, for example, the quit rate out of public sector jobs was just below 9 percent. By 2000, this quit rate had increased to almost 13 percent. Moreover, it is evident that there has been a significant increase in quit rates for all levels of government. In the federal sector, for instance, the quit rate rose from 5.8 to 9.6 percent between 1990 and 2000, while in the local sector the increase was from 8.5 to 13.2 percent. The bottom of Figure 11 illustrates the 
trend in year-to-year entry rates into the public sector. Not surprisingly, since these entry rates are mainly determined by employment demand in the public sector, the entry rates are much more stable over time, hovering between 2 and 3 percent throughout the entire period.

As noted above, the characteristics of the workers who entered — or who left- the public sector in the past two decades should have changed in response to the relative changes in the wage structure. I now turn to a more formal analysis of this hypothesis.

To simplify the analysis, I restrict the study to the sample of "marginal" workers- that is, those workers who either left or entered the public sector during any two-year period. The empirical analysis, therefore, ignores the largest group of workers, those who did not change sectors. This group of non-movers either did not pay attention to the changing opportunities provided by the different evolution of wage structures, or found that, perhaps because of the high transaction costs involved in any move, they could not fully take advantage of the changing opportunities and were "stuck" in their initial placement. By focusing on the sample of movers, the analysis should be able to isolate the impact of the relative compression of wages in the public sector on the sorting of workers across sectors, if any such impact actually exists.

Before proceeding to a more formal study of the impact of the wage structure on the sorting mechanism, it is instructive to examine, at a purely descriptive level, how the average quality of the marginal workers changed during the period under study. To conduct this type of empirical analysis, it is crucial to judiciously match workers across the available CPS-ORG surveys. In particular, consider the workers who are employed in the private sector in some calendar year $t$. By linking these workers in the CPS-ORG data across years $t$ and $t+1$, I can observe the private sector earnings of workers who are about to enter the public sector. Similarly, by linking workers across years $t-1$ and $t$, I can observe the private sector earnings of workers 
who have just left the public sector. In short, in any given CPS-ORG cross-section I can measure the private sector earnings of two distinct groups of workers: workers who are about to enter the public sector and workers who have just left the public sector. The comparison of the private sector earnings of these two groups - and how the wage difference between these groups varies as the public sector wage structure became relatively more compressed-should provide a great deal of information about the impact of the changing wage structures on the sorting of workers across the two sectors. ${ }^{12}$

To easily show the correlation between the quit decision and worker quality, consider the quit behavior exhibited by workers in different parts of the wage distribution. Given my definition of the "marginal" worker — as workers who are either leaving or entering the private sector-I can use the private sector wage distribution in each calendar year to rank all workers in the data. I can then calculate the quit rate out of the public sector for workers in each tercile of the wage distribution. Figure 12 shows the trend in the quit rates for the top tercile relative to the other groups. It is evident that the quit behavior of workers in the top third of the distribution differs substantially from that of workers in the other deciles. In particular, high-skill workers have much lower quit rates, but the quit rate for these high-skill workers rose at a much faster rate during the 1980 s and 1990 s — at the same time that the relative pay for these types of workers was improving substantially in the private sector. ${ }^{13}$

\footnotetext{
12 Ideally, one would want to define three distinct samples of private sector workers in year $t$ by merging the relevant CPS files for calendar years $t-1, t$, and $t+1$ : those workers who are in the private sector in all three years, those who just entered the private sector, and those who are about to leave the private sector. It would be of great interest to estimate the relative wages of the three groups. Unfortunately, the survey design of the CPS does not allow such an exercise since no person can appear in more than two consecutive years of the data. I can obtain the sample of quitters and entrants, but cannot isolate the workers who stayed in the private sector throughout. This data constraint helps further explain why I focus on analyzing the relative wage of the two groups of marginal workers.

13 The trend for the relative entry rate of high-skill workers is less insightful because it is mainly driven by the increasing demand of the public sector for high-skill workers.
} 
To summarize, the judicious merging of CPS-ORG data across years isolates two distinct groups of "marginal" workers who are in the private sector in any given calendar year. The first are workers who have just entered the private sector, and the second are workers who are about to leave the private sector. The comparison of the skills of these two groups of marginal workers should help indicate how the differential changes in the two structures affects the sorting of workers across sectors. In particular, consider the regression model to be estimated in the pooled sample of these marginal workers:

$$
\log w_{i t}=X_{i t} b_{0 t}+\alpha Q_{i t}+\beta \sigma_{t}+\gamma\left(Q_{i t} \times \sigma_{t}\right)+\varepsilon_{i t},
$$

where $w_{i t}$ gives the weekly wage of private-sector worker $i$ at time $t ; X$ is a vector of socioeconomic characteristics (described below); $Q_{i t}$ is a dummy variable set to unity if the worker has just quit the public sector, and set to zero if the worker is about to enter the public sector; and $\sigma$ is a measure of the relative dispersion in the public sector at time $t \cdot{ }^{14}$ For simplicity, I use the sex-specific ratio of standard deviations between the public and private sectors as the measure of dispersion. Since the wage structure evolved somewhat differently for male and female workers, the variable $\sigma_{t}$ takes on a different value for men and women at any given point in time. The parameter of interest in this regression model is the coefficient $\gamma$, which indicates how the wage differential between workers who have just quit the public sector and workers who are about to enter the public sector varies with respect to the relative dispersion in

\footnotetext{
14 The regression model also includes a vector of dummy variables indicating if the "marginal" worker is in the federal sector, the state sector, or the local sector. In addition, the regression includes a measure of the publicprivate sector wage differential, which clearly can affect the number of workers who move across sectors, and thereby intensify or dilute the selection effect. The inclusion of these variables in the regression model does not alter the qualitative implications of the results reported below.
} 
the public sector. I have argued that the wage differential between the "quitters" and the "entrants" should be larger when there is more compression in the public sector (i.e., the quitters will tend to be high-skill workers, and high-skill workers will not want to enter the public sector). The coefficient $\gamma$, therefore, should be negative.

I estimated this regression model on the sample drawn from the CPS-ORG data by pooling all of the marginal workers over all the years for which the merging could be conducted. Table 3 presents the estimates of the coefficient $\gamma$. Consider the first row of the table, which corresponds to the regression model specified in equation (1). In the absence of any variables standardizing for differences in observable skills across workers, the first column of the table reports a statistically significant estimate of -.414 for the coefficient $\gamma$.

It is instructive to interpret this coefficient in terms of a specific simulation of the model. In particular, I documented earlier (see Figures 5 and 6) that the relative ratio of standard deviations between the public and private sectors declined by about .15 percentage points between 1976 and 1990. One can use the estimated coefficient of -.414 to predict the impact of this observed decline in relative wage dispersion on the wage differential between the workers who have just quit the public sector and workers who are about to enter the public sector. In particular, the relative compression of the public sector wage distribution increased the wage differential between quitters and entrants by 6 percentage points (or -.414 times -.15 ). It is evident, therefore, that the impact of the wage structure on the relative quality of workers that the public sector attracts and retains is not only statistically significant, but numerically important.

The other columns of the first row of Table 3 investigate the nature of this sorting effect in more detail. The second column addresses the possibility that the variable measuring the relative dispersion in the public sector wage structure is just "standing in" for a time trend. As I 
showed earlier, relative dispersion in the public sector declined steadily since 1970. It may well be that for some unrelated reason the wage gap between the quitters and the entrants was rising over time, and the regression coefficient $\gamma$ is just capturing a spurious correlation. To net out this spurious effect, I add a vector of dummy variables indicating the calendar year in which the observation is observed to the regression model. This vector is not completely collinear with the relative dispersion variable $\left(\sigma_{t}\right)$ because the dispersion variable takes on different values for men and women. By including these period effects, the coefficient $\gamma$ now measures the impact of relative dispersion on the wage gap between quitters and entrants in any particular year. It is evident that the estimated effect remains negative and significant. In fact, the estimated coefficient of -.289 implies that the .15 percentage point drop in the relative dispersion of the public sector wage distribution increased the wage gap between those who have just quit the public sector and those who are about to enter it by about 4 percent points.

The last column of the table introduces a number of standardizing variables in the regression model, including the age, race, educational attainment, and region of residence of the worker. Even after adjusting for differences in these variables across workers, as well as for period effects, the data reveal a link between the sorting of workers and the wage structure (although the coefficient is not significant). There is a possibility, however, that the regression is "over-controlling" by including these socioeconomic characteristics. After all, the different evolutions of the wage structures in the two sectors will lead different types of workers (such as more educated workers) to choose different sectors.

The remaining rows of the table look at alternative measures of the impact of relative wage compression on worker quality. Instead of using the log weekly wage as the dependent variable in the regression model, the dependent variable in the second row indicates if the worker 
is in the top tenth of the private sector wage distribution. The coefficient $\gamma$ now measures the difference in the probability of being in the top tenth of the distribution between quitters and entrants. Finally, the dependent variable in the third row is the probability that the worker is in the top third of the wage distribution.

Table 3 clearly shows that there are significant sorting effects when worker quality is defined in terms of worker placement in the private sector wage distribution. Consider, for example, the difference in the probability that quitters and entrants are in the top third of the wage distribution. This difference is very sensitive to the relative compression of wages in the public sector. In particular, the .15 percentage point decline in the relative dispersion of the public sector implies about a 5 percentage point increase in the difference between the probability that a quitter and an entrant are in the top third of the wage distribution. In short, the relative compression of wages in the public sector significantly altered the incentives of persons in the upper tail of the wage distribution to consider jobs in the public sector.

The sorting evidence presented in Table 3 aggregates all the levels of government into a single group, the public sector, and netted out any sectoral effects on the wage gap between quitters and entrants by including dummy variables indicating if the marginal worker was in the federal, state, or local governments. Table 4 reports the results when the regression model is estimated separately for the marginal workers in each sector of government. ${ }^{15}$ Each of the three samples being considered, therefore, contains workers who either have just quit or are about to enter a particular level of government (e.g., the state government). The relative dispersion variable $\left(\sigma_{t}\right)$ is now defined in terms of the ratio of standard deviations between the particular government sector and the private sector. Since the measure of within-sector relative dispersion 
is noisier because of the smaller samples, it is not surprising that the standard errors of the estimated sorting effect tend to be higher than in the analysis that pooled observations across government sectors. Nevertheless, the data are roughly consistent with the hypothesis that the relative compression of wages in each of the levels of government in the public sector adversely affected the quality of the workforce in that sector.

In the state government sector, for example, the relative measure of dispersion dropped by .1 percentage points between 1976 and 2000. The estimate of the coefficient $\gamma$ in Table 4 (in the absence of any controlling variables) is -.835 . This coefficient implies that the observed compression of wages in the state government sector (relative to the private sector) generated an 8 percentage point increase in the wage gap between workers who have just left the state government sector and workers who are about to enter it, an effect that is both numerically and statistically significant. The evidence tends to be weakest for federal workers, where most of the estimated coefficients are negative, but not statistically significant.

\section{Summary}

This paper documents that the wage distributions in the public and private sectors evolved in different ways in the past four decades. In general terms, the public-private sector pay gap between the typical public sector worker and a comparable private sector worker was relatively constant for men between 1960 and 2000, but declined substantially for women. Equally important, prior to 1970 , at the time when public sector employment was rising rapidly, wage dispersion in the public sector was increasing relative to wage dispersion in the private

\footnotetext{
15 The measure of relative dispersion used in the regression models is the measure of compression that applies to the particular sector (i.e. federal, state, or local government).
} 
sector. Beginning in the 1970s, however, this situation reversed, and there has been a significant relative compression of the wage distribution in the public sector during the past two decades.

The differential shifts in the wage structures of the two sectors will likely affect labor supply behavior by altering the sorting of workers between the sectors. As long as the correlation between economic performance in the public and private sectors is strong and positive (so that the same persons tend to be relatively successful regardless of where they work), these labor supply responses suggest that high-skill workers will increasingly want to be employed in the private sector.

This paper used data drawn from the Current Population Surveys to investigate if such a supply response occurred. The evidence suggests that as the wage structures evolved, the relative skills of the "marginal" persons who moved across sectors also changed significantly. For example, the wage differential between persons who had just quit the public sector and workers who were about to enter that sector is strongly and negatively correlated with the relative dispersion of incomes in the public sector. Put differently, as the wage structure in the public sector became relatively more compressed, the public sector found it harder to attract and retain high-skill workers. In short, the substantial widening of wage inequality in the private sector and the relatively more stable wage distribution in the public sector created "magnetic effects" that altered the sorting of workers across sectors, with high-skill workers becoming more likely to end up in the private sector.

Although most studies of pay determination in the public sector focus on the earnings gap between the typical worker in the public sector and his statistical counterpart in the private sector, it is clear that the difference in the shape of the wage distributions between the two sectors plays a significant role in determining the public sector's ability to attract and retain a 
high-quality workforce. The analysis suggests that future policy discussions of public sector wages need to pay a great deal more attention to the relative dispersion in the income opportunities offered to government workers. 


\section{REFERENCES}

Autor, David H., Lawrence F. Katz, and Alan B. Krueger. "Computing Inequality: Have Computers Changed the Labor Market?” Quarterly Journal of Economics, Vol. 113, No. 4 (November 1988): 1169-1213.

Black, Matthew; Robert Moffitt, and John. T. Warner. "The Dynamics of Job Separation: The Case of Federal Employees," Journal of Applied Econometrics, Vol. 5, No. 3. (July-August 1990): 245-262.

Blank, Rebecca M. "An Analysis of Workers' Choice between Employment in the Public and Private Sectors," Industrial and Labor Relations Review, Vol. 38, No. 2. (January 1985): 211-224.

Borjas, George J. "Wage Determination in the Federal Government: The Role of Constituents and Bureaucrats," Journal of Political Economy Vol. 88, No. 6 (December 1980): 1110-1147.

Borjas, George J. "The Politics of Employment Discrimination in the Federal Bureaucracy," Journal of Law and Economics, Vol. 25, No. 2 (October 1982): 271-299.

Borjas, George J. "Electoral Cycles and the Earnings of Federal Bureaucrats," Economic Inquiry, Vol. 22, No. 4 (October 1984): 447-459.

Bound, John and George Johnson. "Changes in the Structure of Wages in the 1980s: An Evaluation of Alternative Explanations," American Economic Review, Vol. 82, No. 3 (June 1992): 371-392.

Craig, Lee A. "The Political Economy of Public-Private Compensation Differentials: The Case of Federal Pensions," Journal of Economic History, Vol. 55, No. 2. (June 1995): 304-320.

Ehrenberg, Ronald G. and Joshua L. Schwarz. "Public Sector Labor Markets," in Orley Ashenfelter and Richard Layard, editors, Handbook of Labor Economics, Vol. 2. Amsterdam: North-Holland, 1986: 1219-1268.

Freeman, Richard B. "How Much Has De-Unionization Contributed to the Rise in Male Earnings Inequality," in Sheldon Danzinger and Peter Gottschalk, editors, Uneven Tides: Rising Inequality in America. New York: Russell Sage Foundation, 1993: 133-163.

Gregory, Robert G. and Jeff Borland. "Recent Developments in Public Sector Labor Markets," in Orley Ashenfelter and David Card, eds., Handbook of Labor Economics, Volume 3C. Amsterdam: North-Holland, 1999: 3573-3630.

Gyourko, Joseph and Joseph Tracy. "An Analysis of Public- and Private-Sector Wages Allowing for Endogenous Choices of Both Government and Union Status," Journal of Labor Economics, Vol. 6, No. 2. (April 1988): 229-253. 
Hundley, Greg, "The Effects of Comparable Worth in the Public Sector on Public/Private Occupational Relative Wages," Journal of Human Resources, Vol. 28, No. 2. (Spring, 1993): 318-342.

Ippolito, Richard. “Why Federal Workers Don't Quit?” Journal of Human Resources, Vol. 22, No. 2 (Spring 1987): 281-299.

Juhn, Chinhui, Kevin M. Murphy, and Brooks Pierce. "Wage Inequality and the Rise in Returns to Skill," Journal of Political Economy, Vol. 101, No. 3 (June 1993): 410-442.

Katz, Lawrence F. and David H. Autor. "Changes in the Wage Structure and Earnings Inequality." In Orley Ashenfelter and David Card, eds., Handbook of Labor Economics, Volume 3A. Amsterdam: North-Holland, 1999: 1463-1555.

Katz, Lawrence F. and Alan B. Krueger. "Changes in the Structure of Wages in the Public and Private Sectors," Research in Labor Economics, Volume 12 (1991): 137-172.

Katz, Lawrence F. and Kevin M. Murphy. "Changes in the Wage Structure, 1963-87: Supply and Demand Factors," Quarterly Journal of Economics, Vol. 107, No. 1 (February 1992): 35-78.

Krueger, Alan B. "The Determinants of Queues for Federal Jobs," Industrial and Labor Relations Review, Vol. 41, No. 4 (July 1988): 567-581.

Moore, William J. and Robert J. Newman. "Government Wage Differentials in a Municipal Labor Market: The Case of Houston Metropolitan Transit Workers," Industrial and Labor Relations Review, Vol. 45, No. 1. (October 1991): 145-153.

Moulton, Brent R. "A Reexamination of the Federal-Private Wage Differential in the United States," Journal of Labor Economics, Vol. 8, No. 2 (April 1990): 270-293.

Murphy, Kevin M. and Finis Welch. "The Structure of Wages," Quarterly Journal of Economics, Vol. 107, No. 1 (February 1992): 215-326.

Perloff, Jeffrey and Michael L. Wachter. "Wage Comparability in the U.S. Postal Service," Industrial and Labor Relations Review, Vol. 38, No. 1. (October 1984): 26-35.

Smith, Sharon. Equal Pay in the Public Sector: Fact or Fantasy. Princeton: Princeton University, Industrial Relations Section, 1977. 
Figure 1

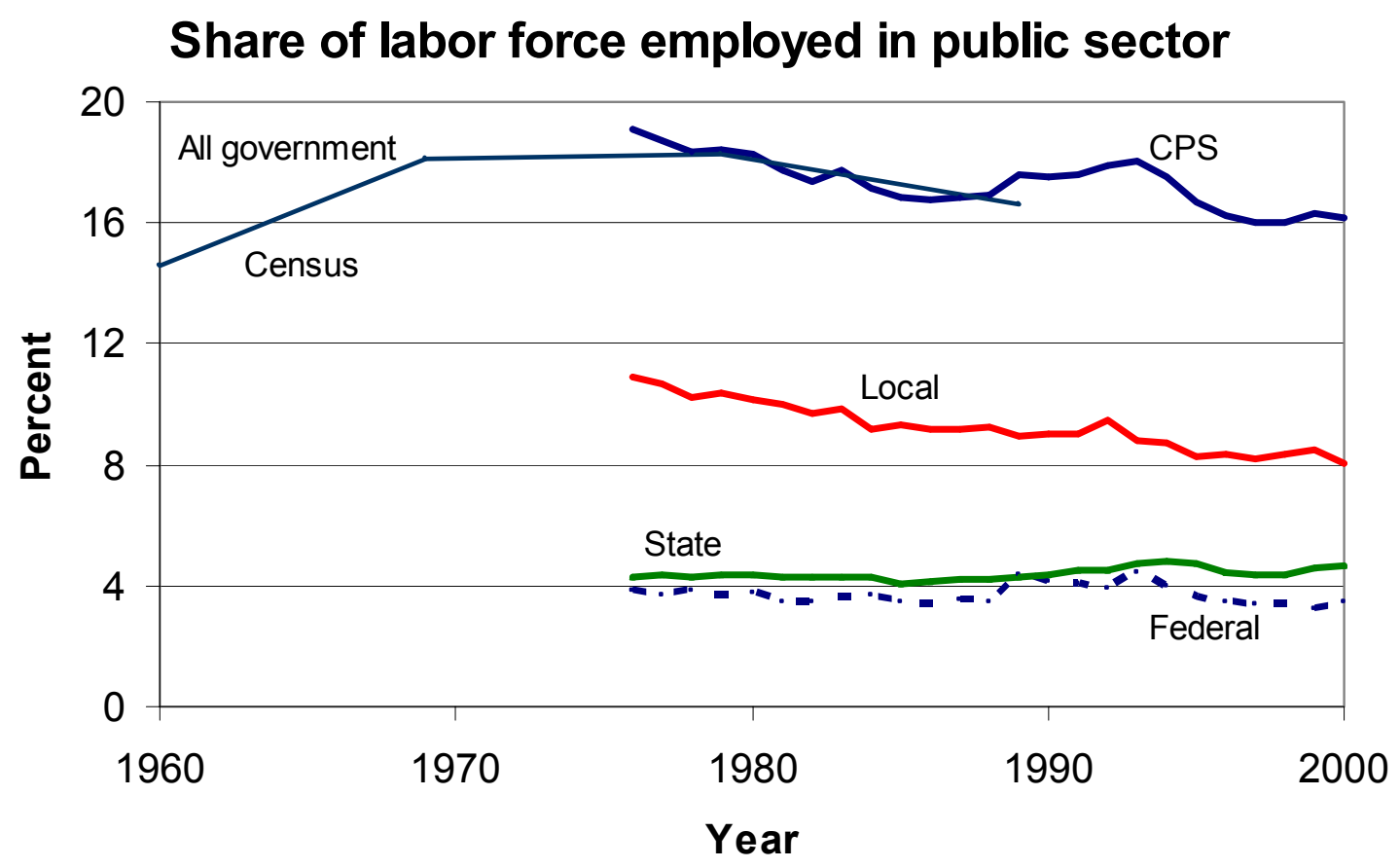


Figure 2

Share of male workforce in public sector

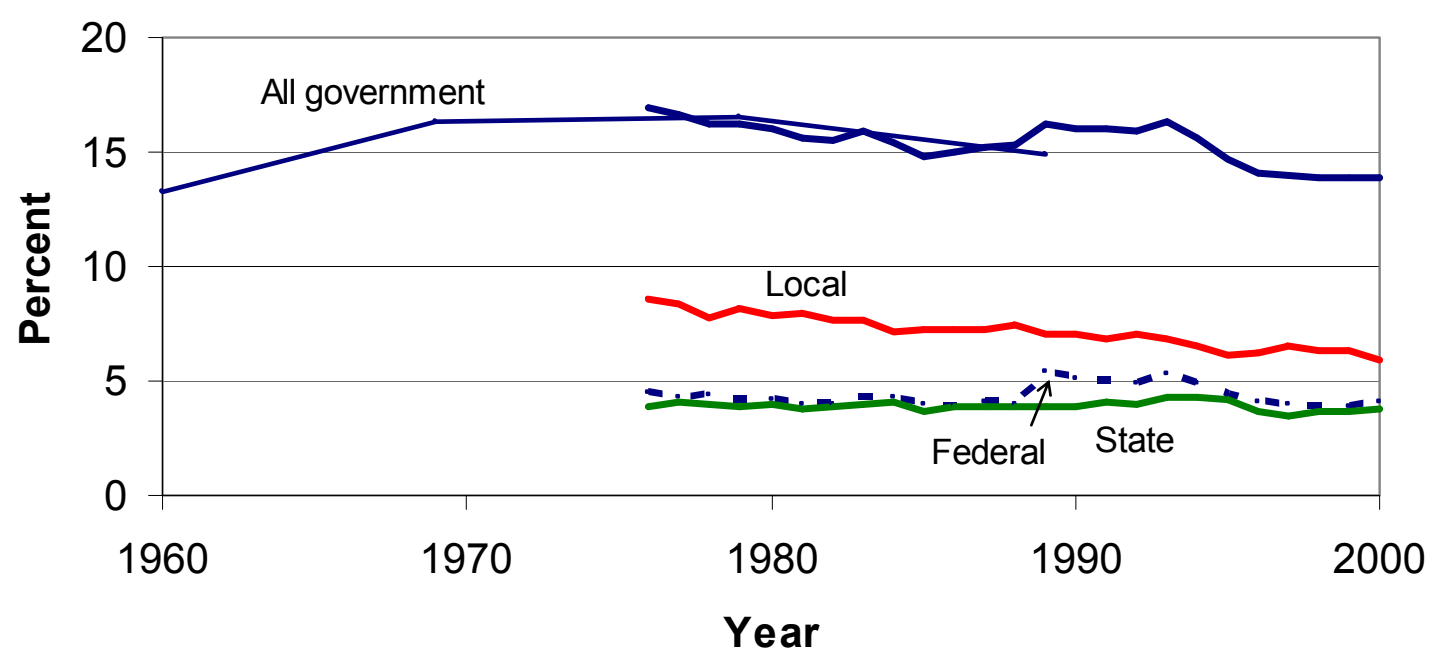

Share of female workforce in public sector

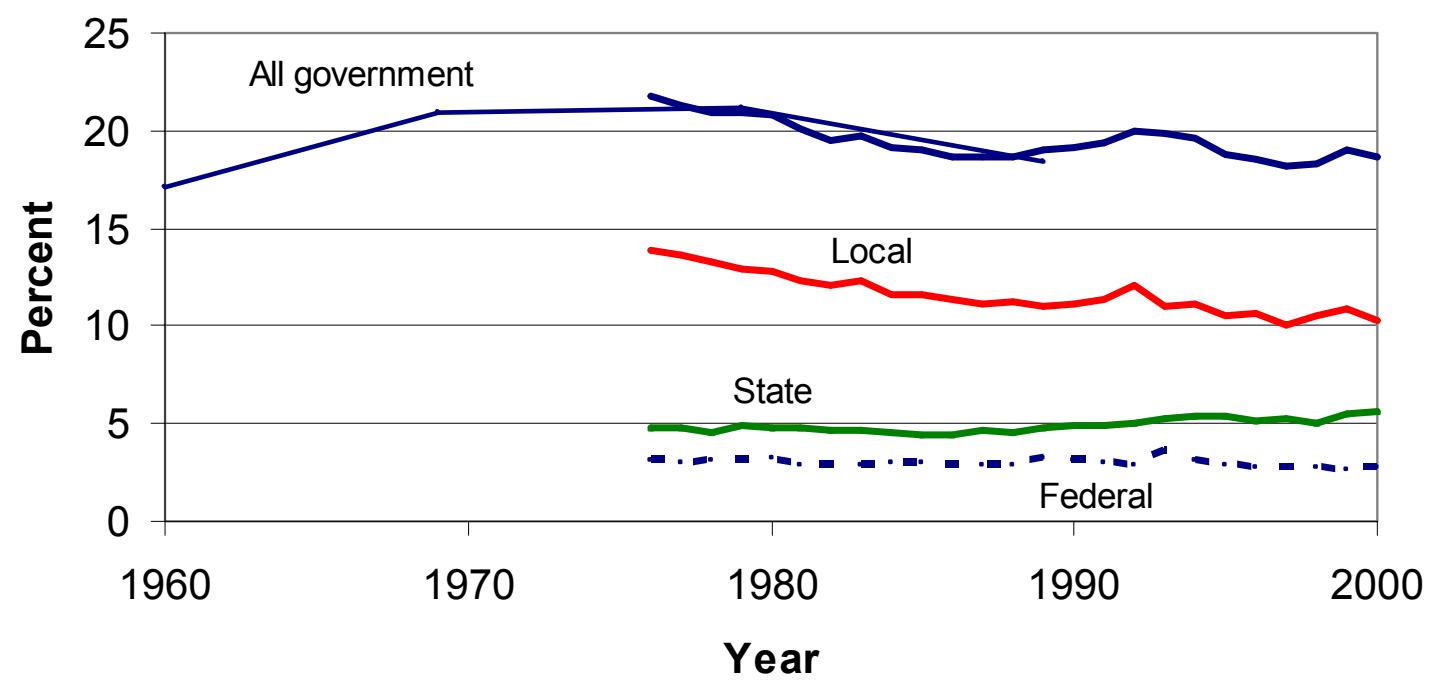


Figure 3

Public-private wage differential for men

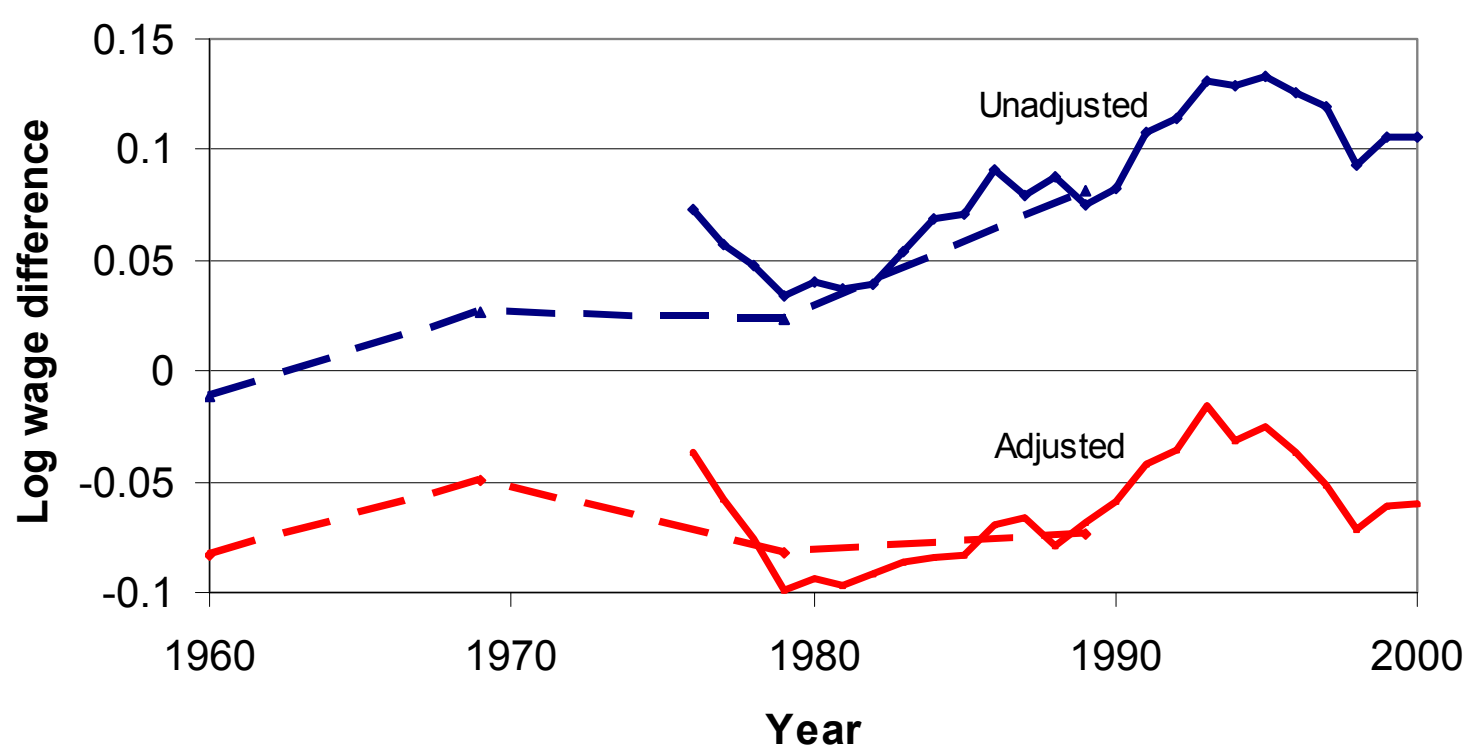

Public-private wage differential for women

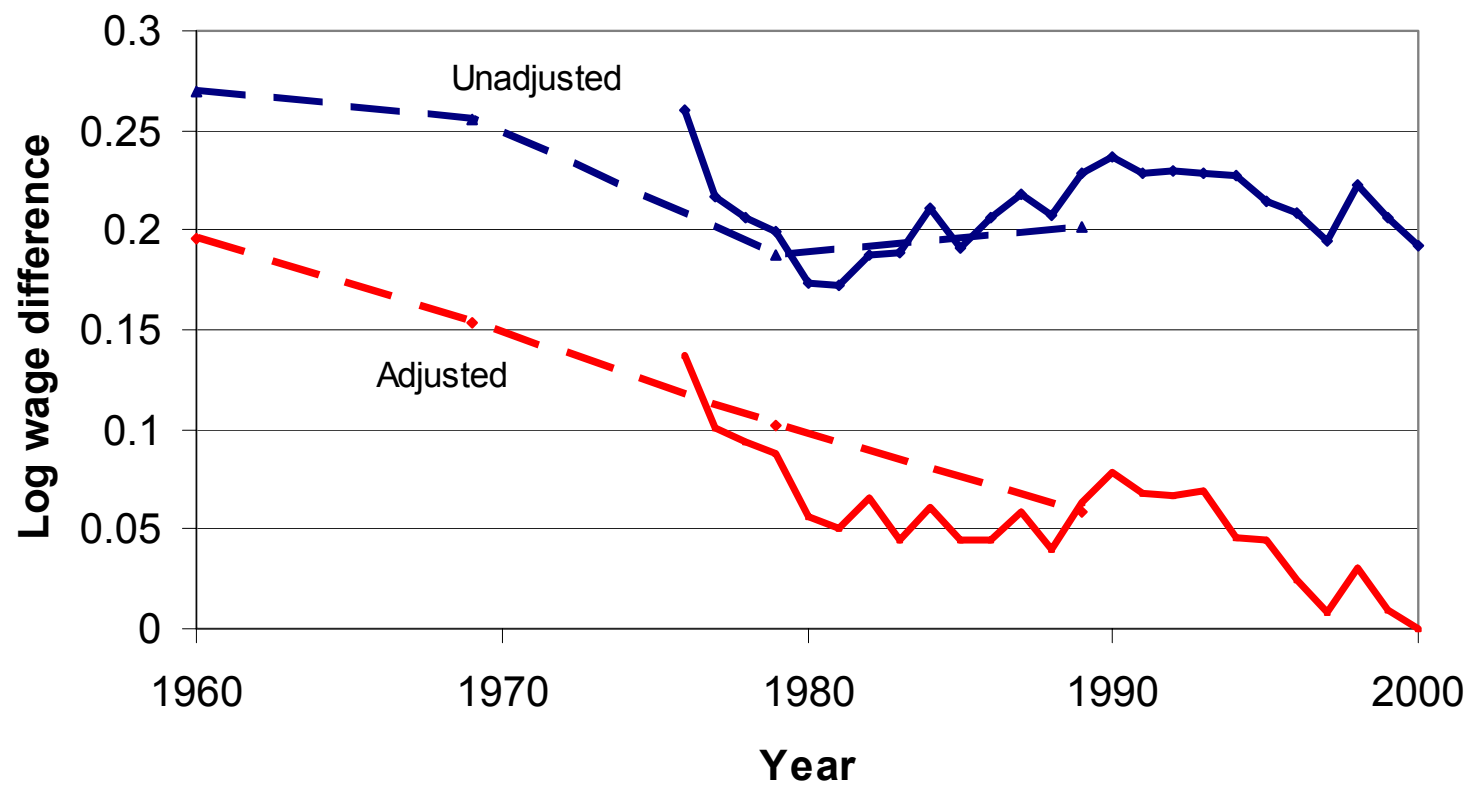


Figure 4

Adjusted public-private wage differential for men, by sector

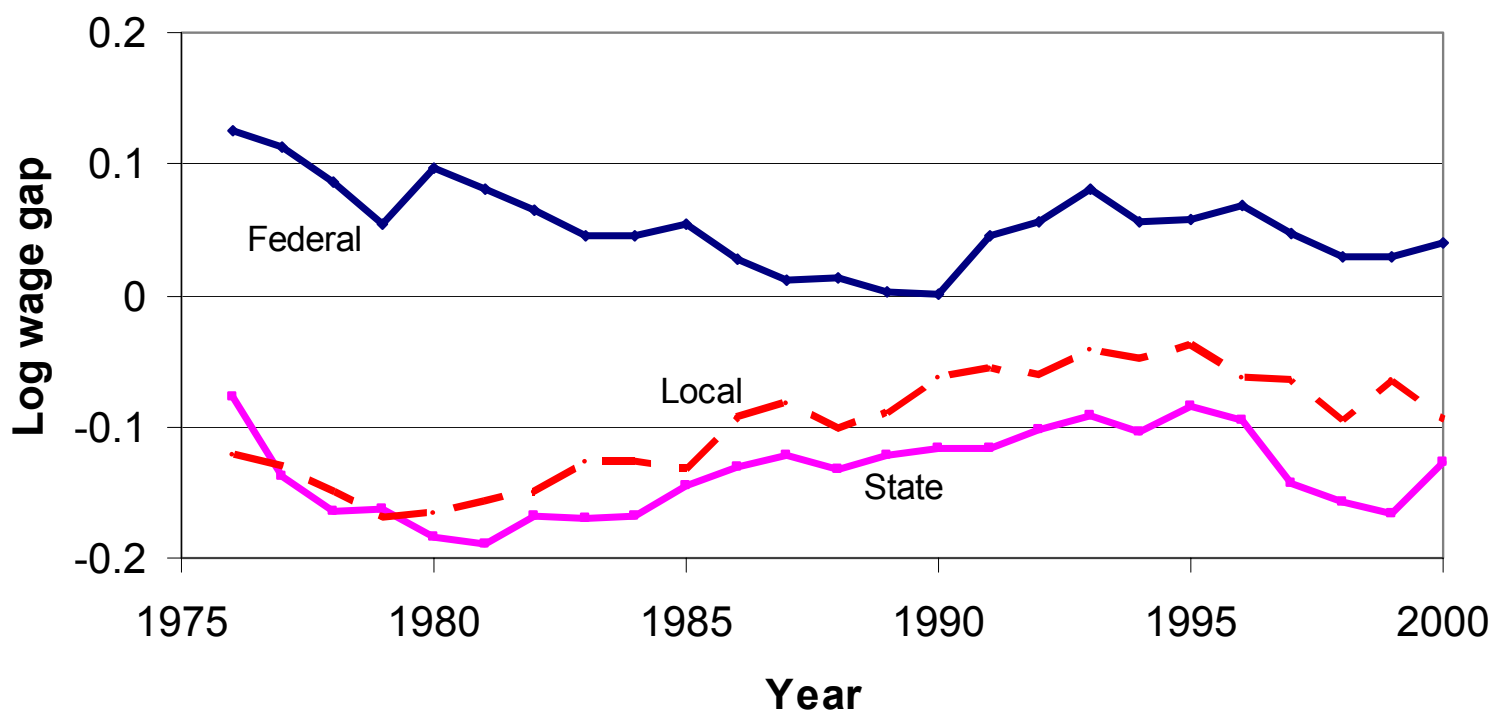

Adjusted public-private wage differential for women, by sector

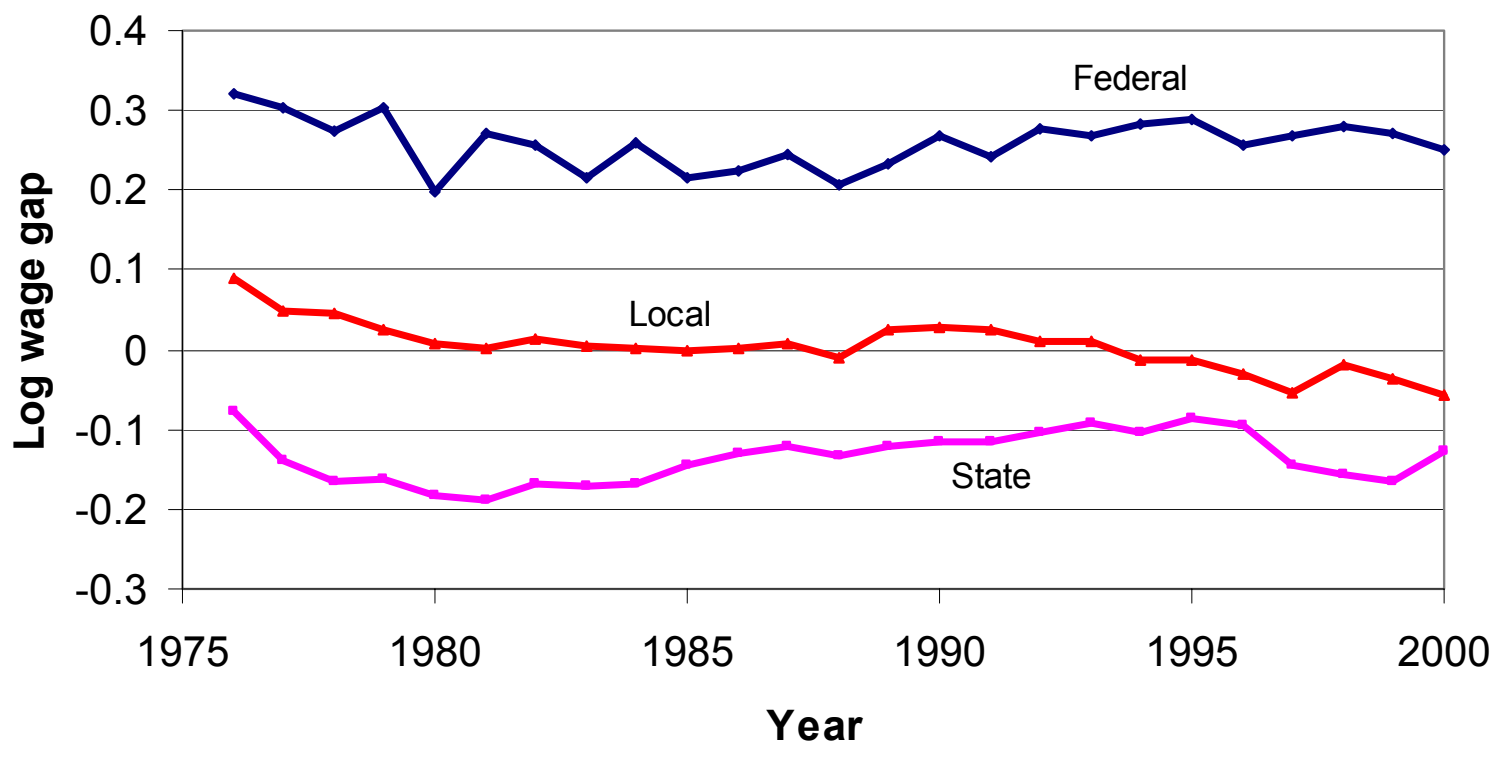




\section{Figure 5}

Standard deviation of log weekly wage, men

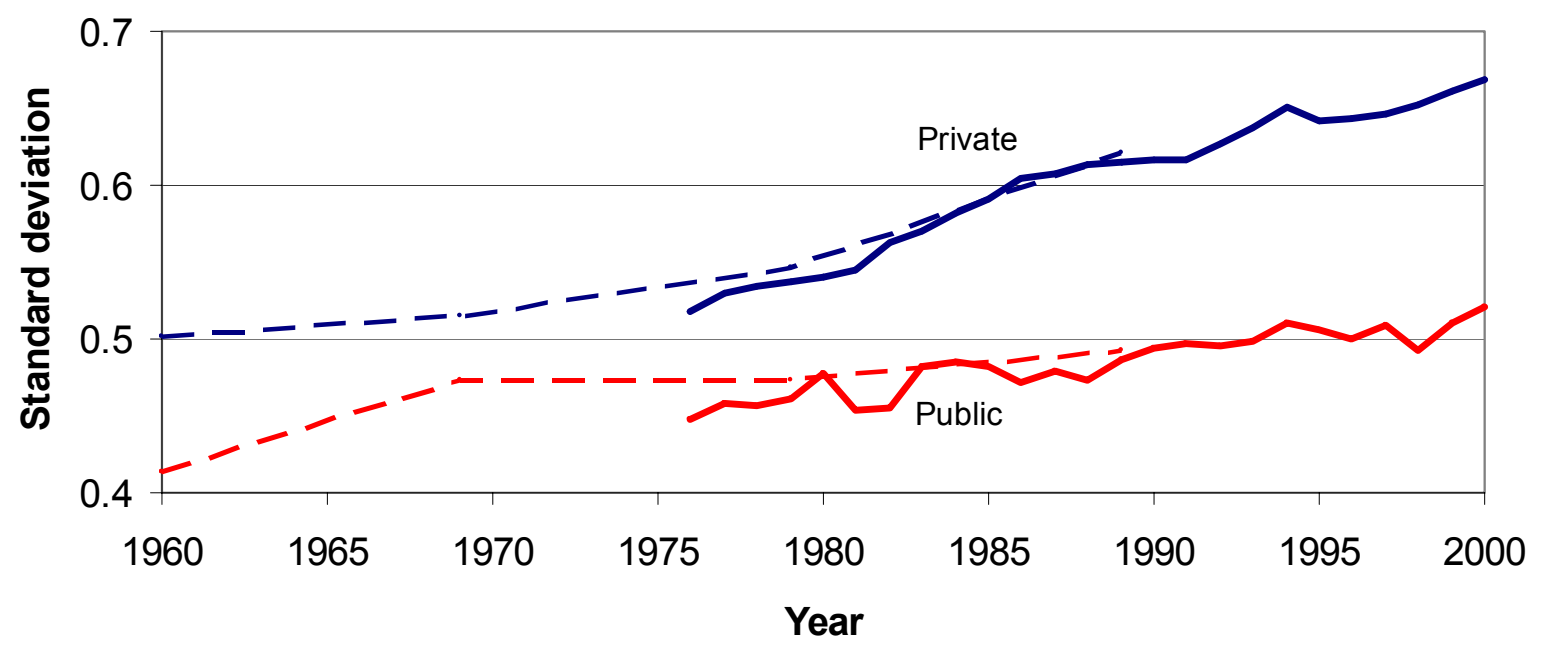

Ratio of standard deviations in public-private sector, men

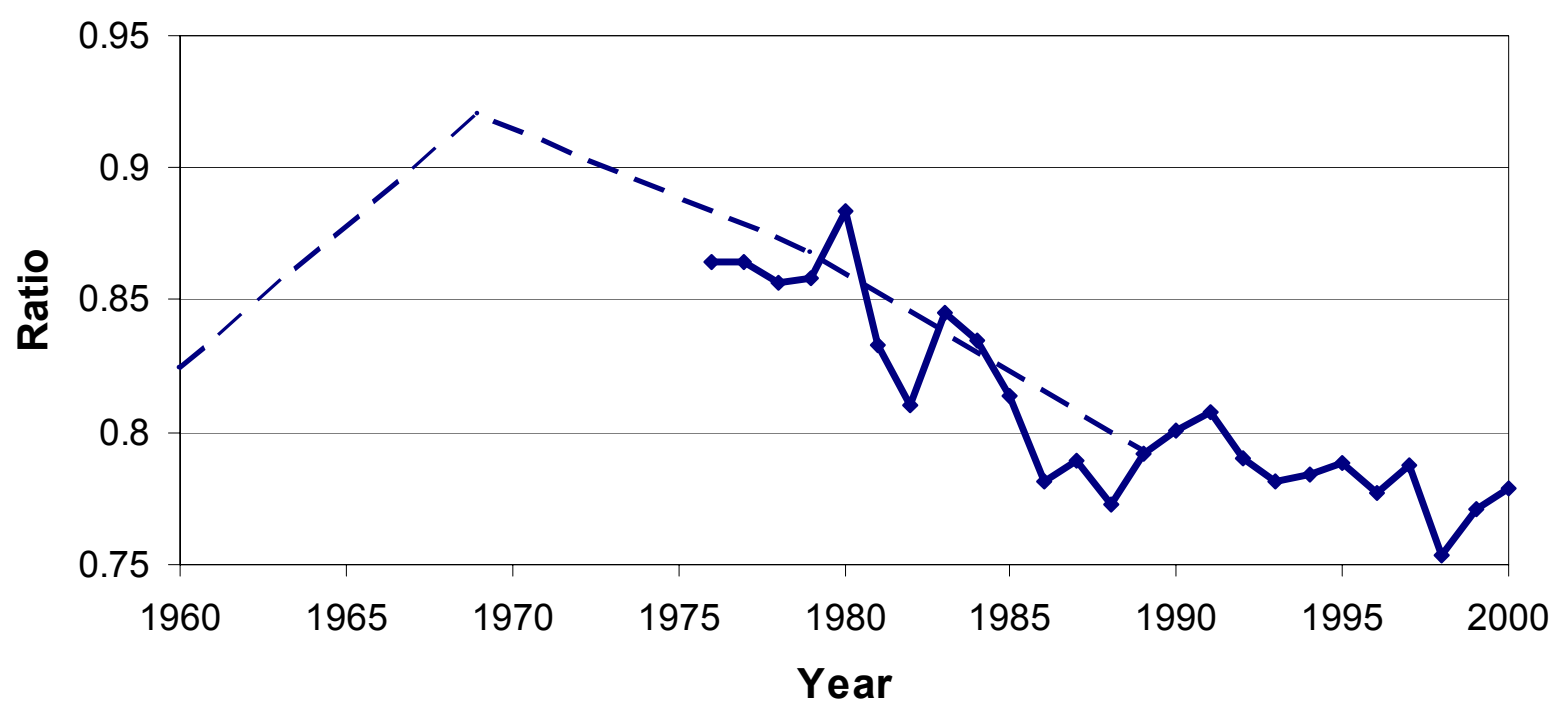


Figure 6

Standard deviation of log weekly wage, women

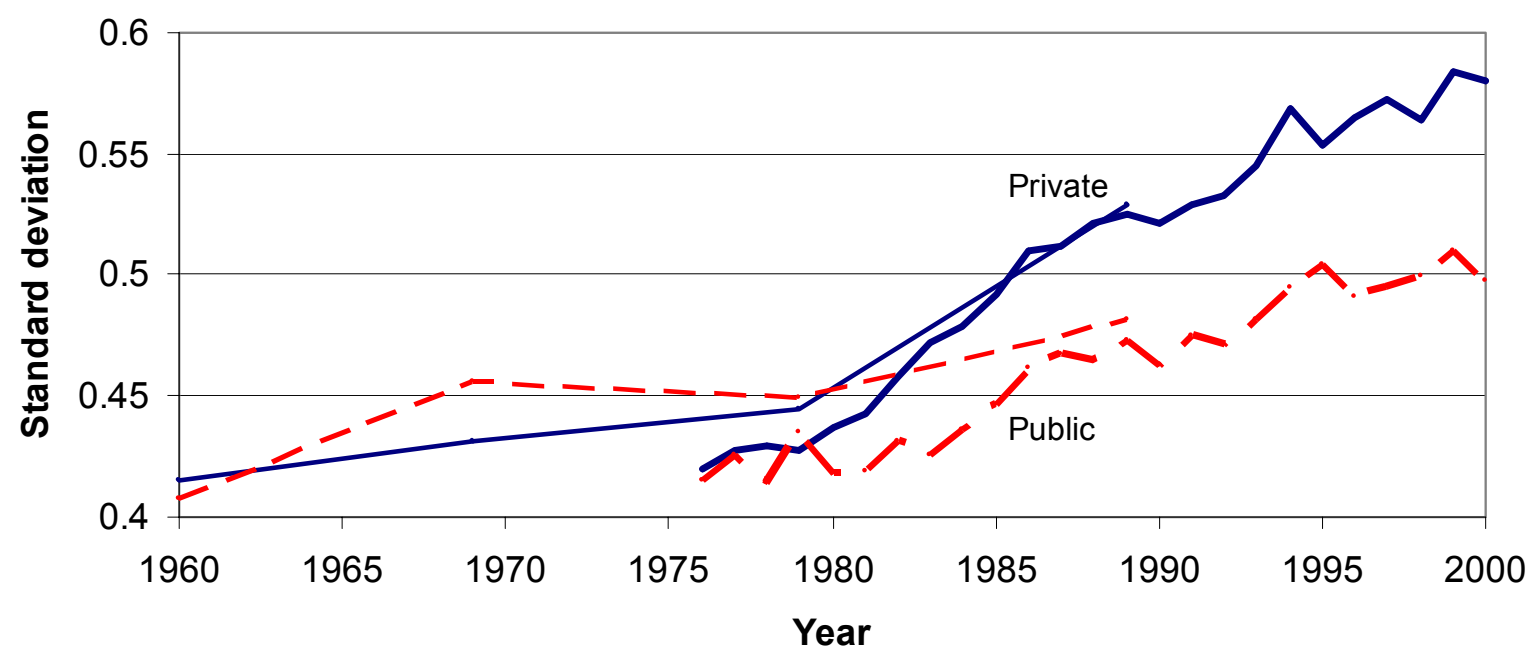

Ratio of standard deviations in public-private sector, women

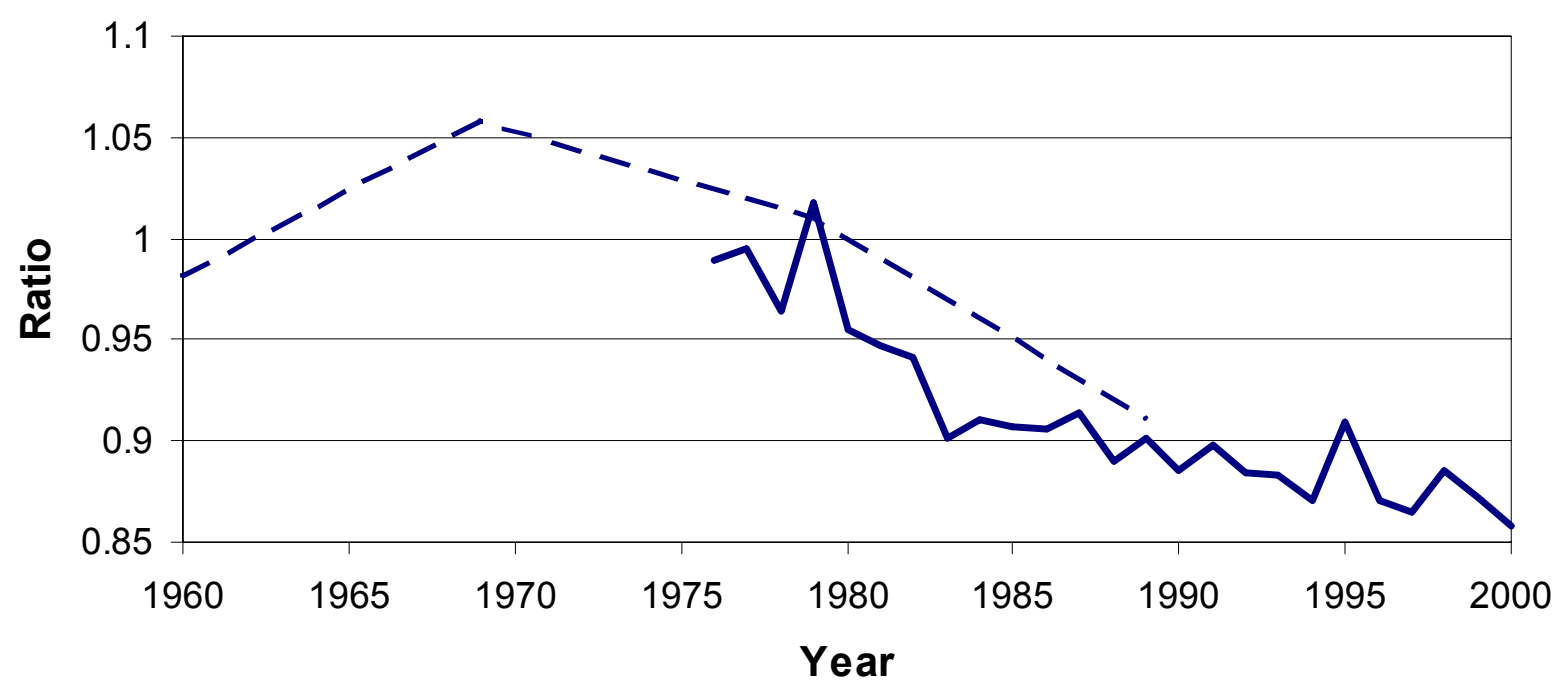




\section{Figure 7}

Trends in 90-10 wage differential, men

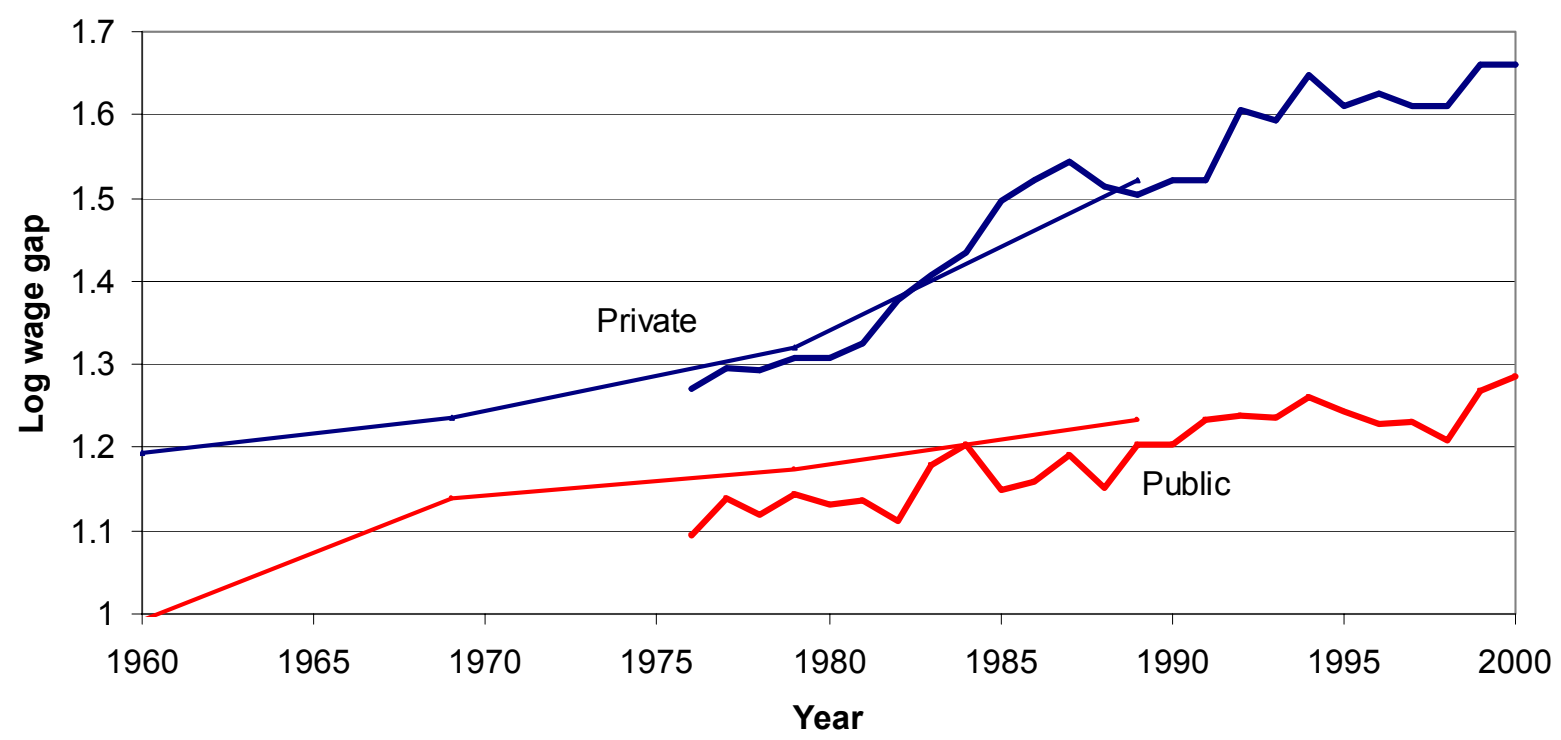

Trends in 90-10 wage differential, women

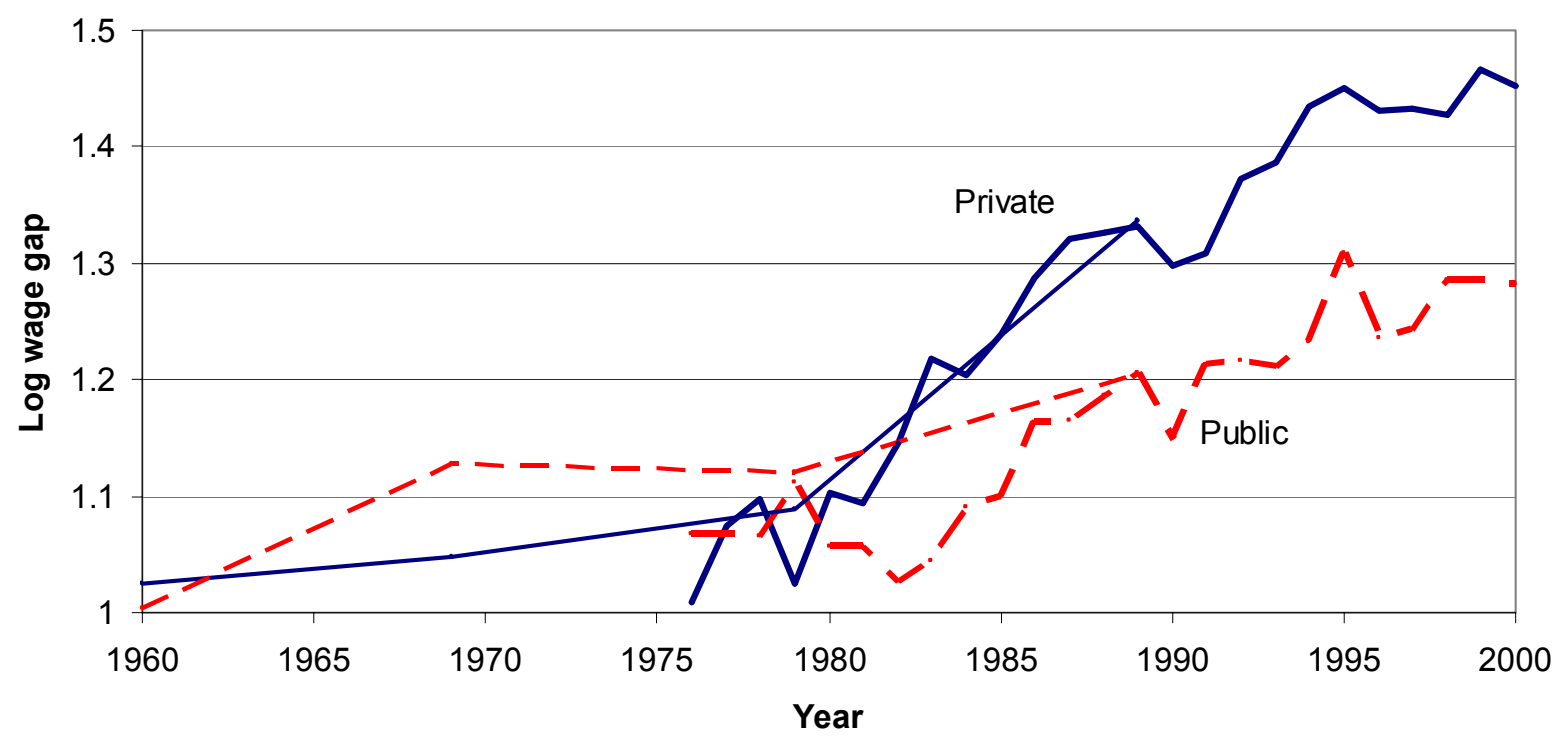


Figure 8

Trends in relative $\mathbf{9 0 - 1 0}$ differential for men, by sector

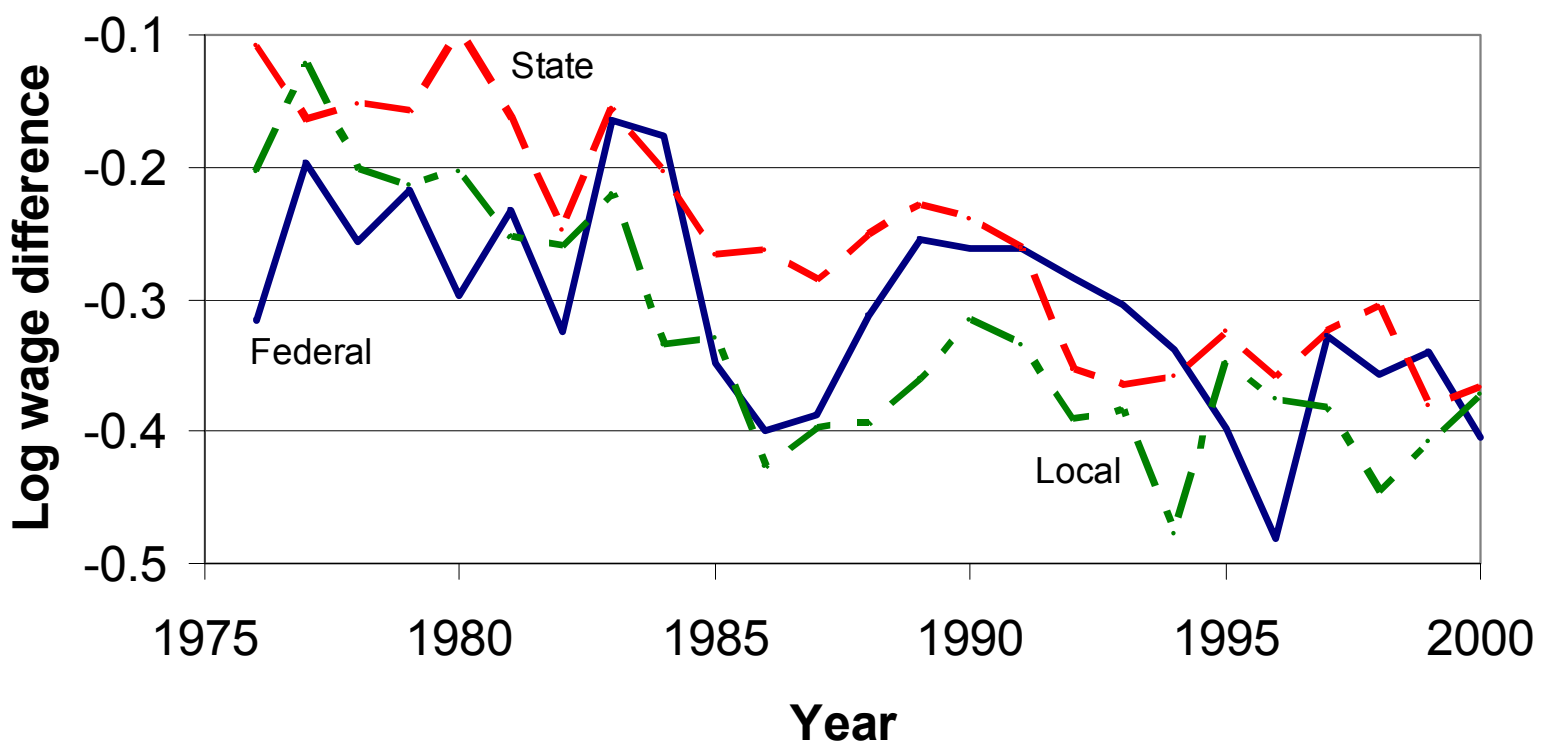

Trends in relative $\mathbf{9 0 - 1 0}$ differential for women, by sector

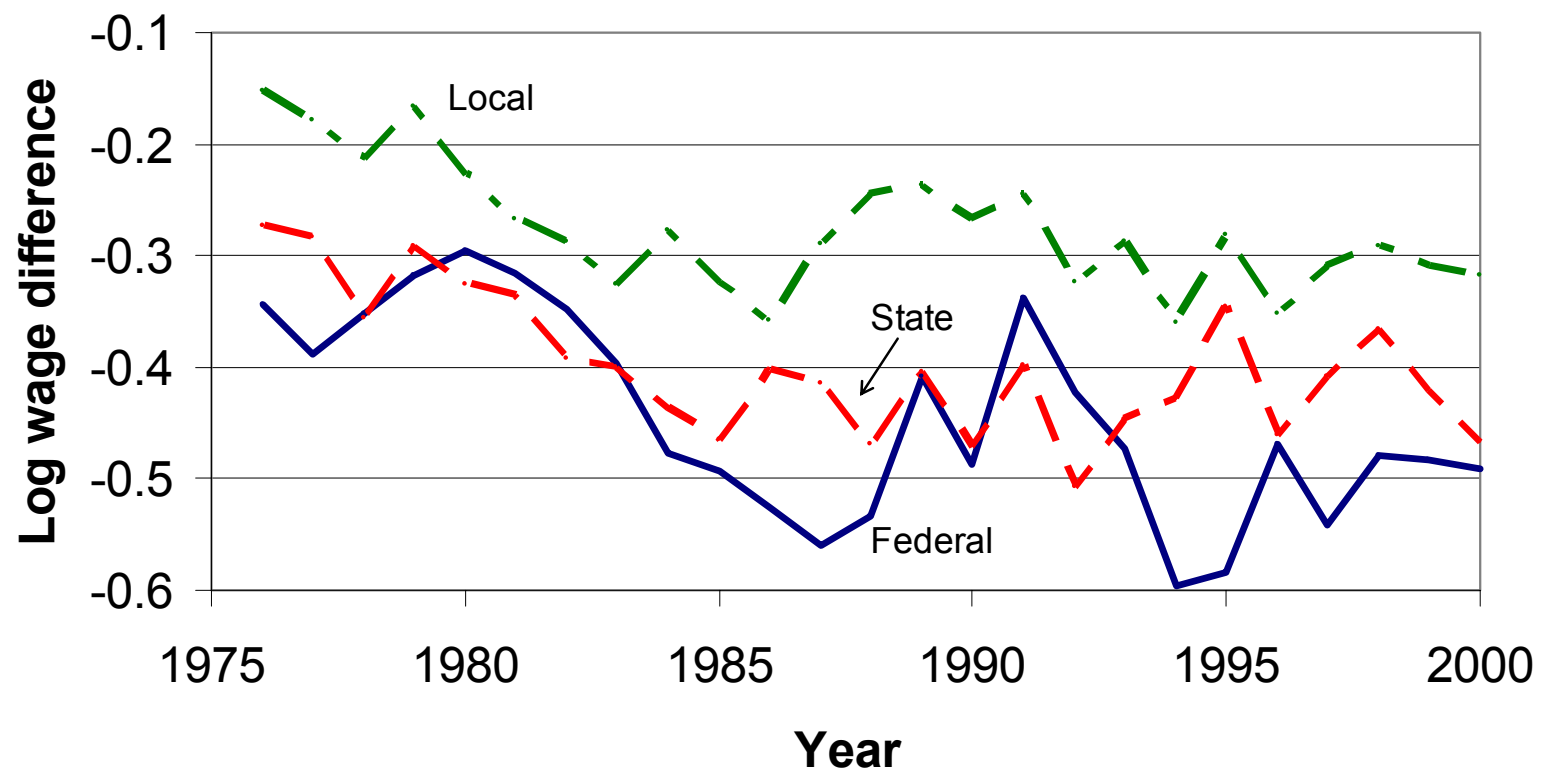


Figure 9

Relative wage of college graduates, men

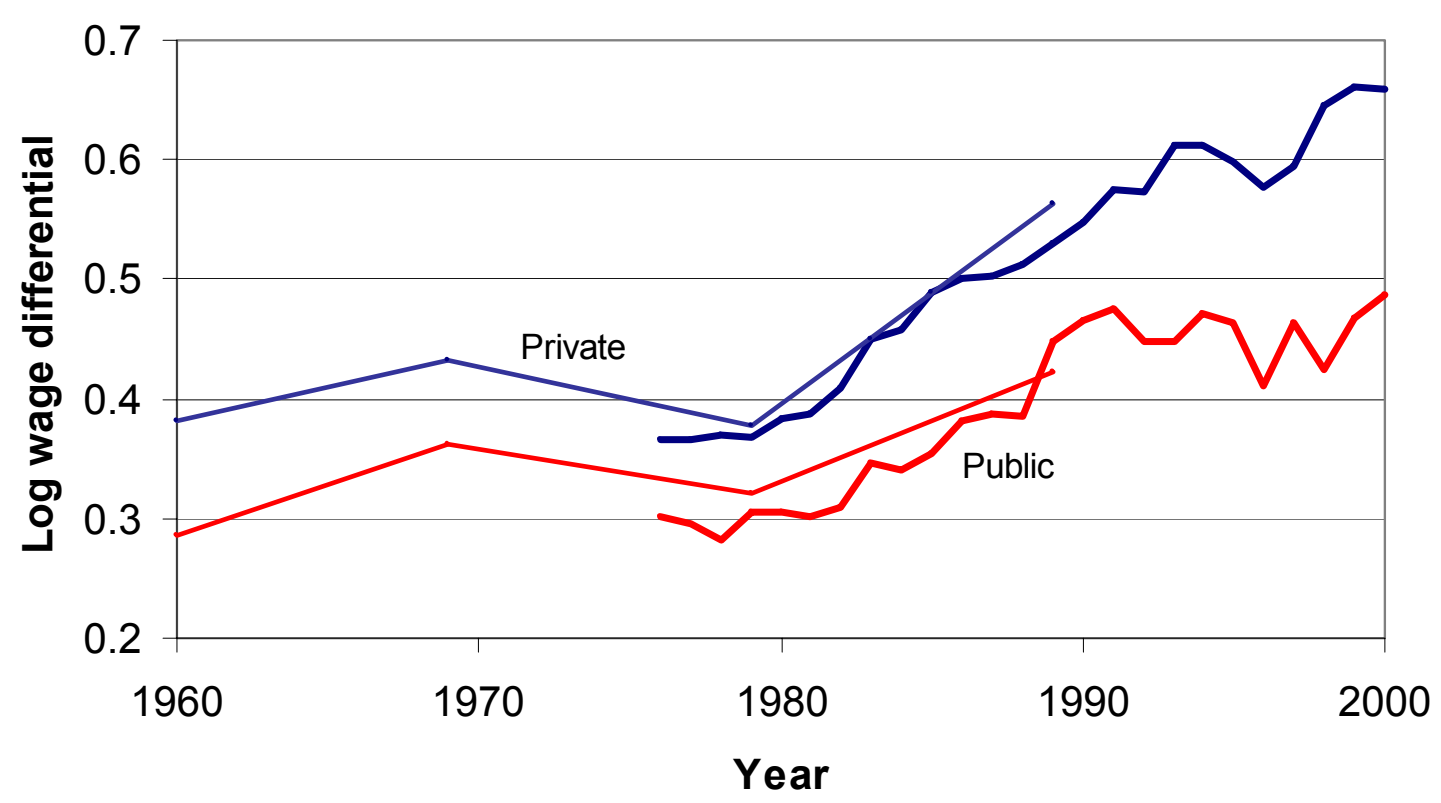

Relative wage of college graduates, women

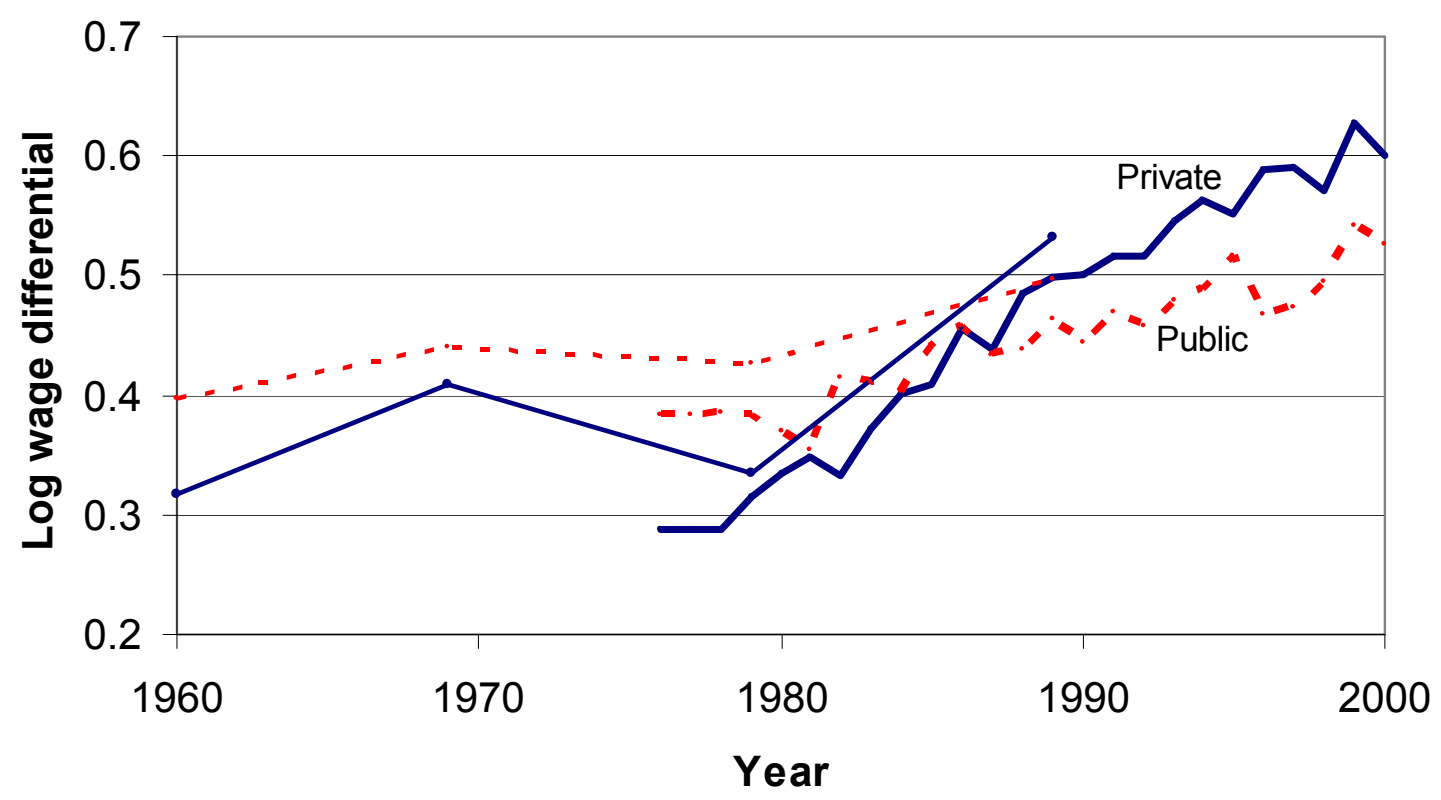


Figure 10

Ratio of mean-square-error in public-private sector

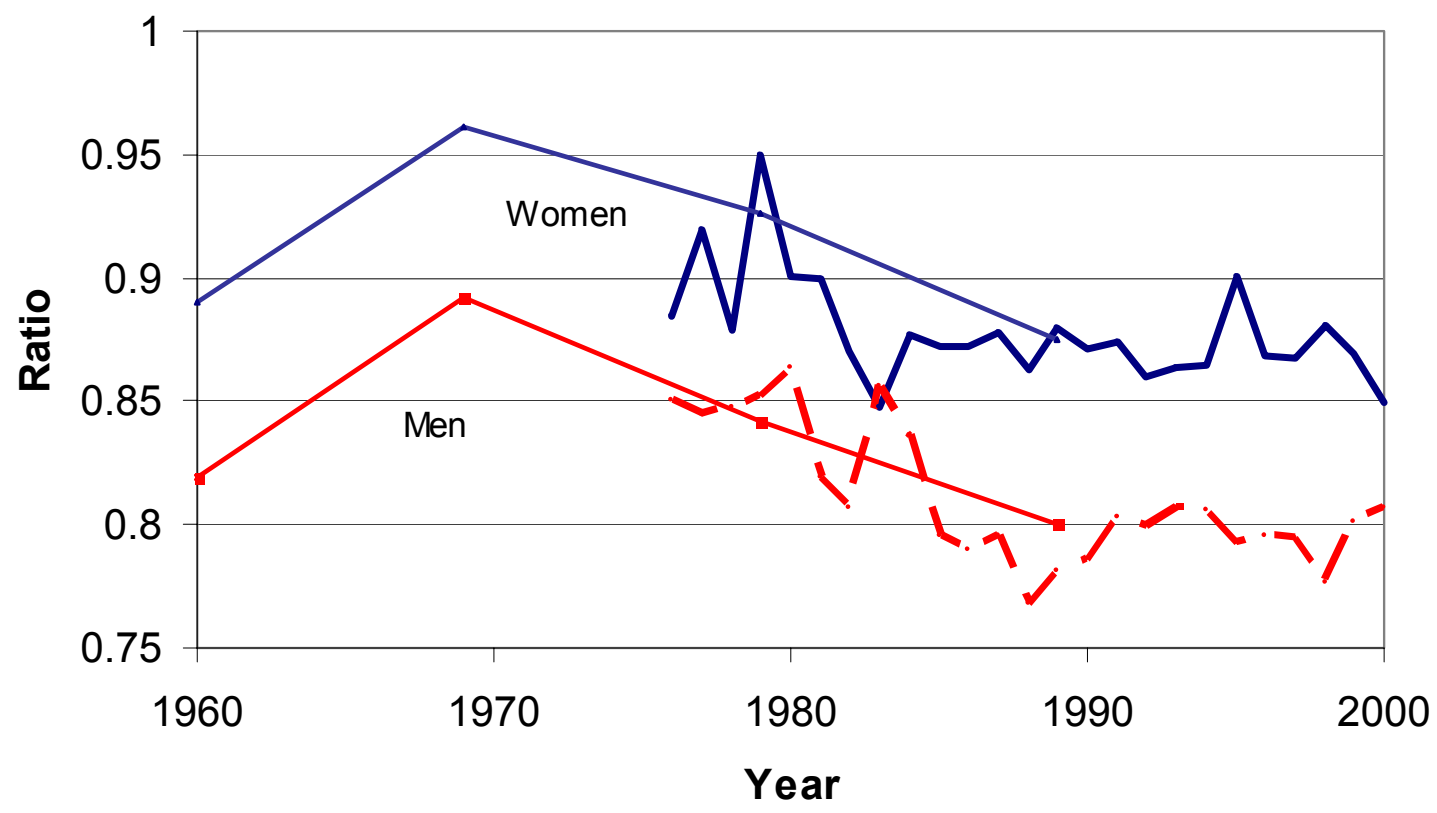


Figure 11

Quit rates from the public sector

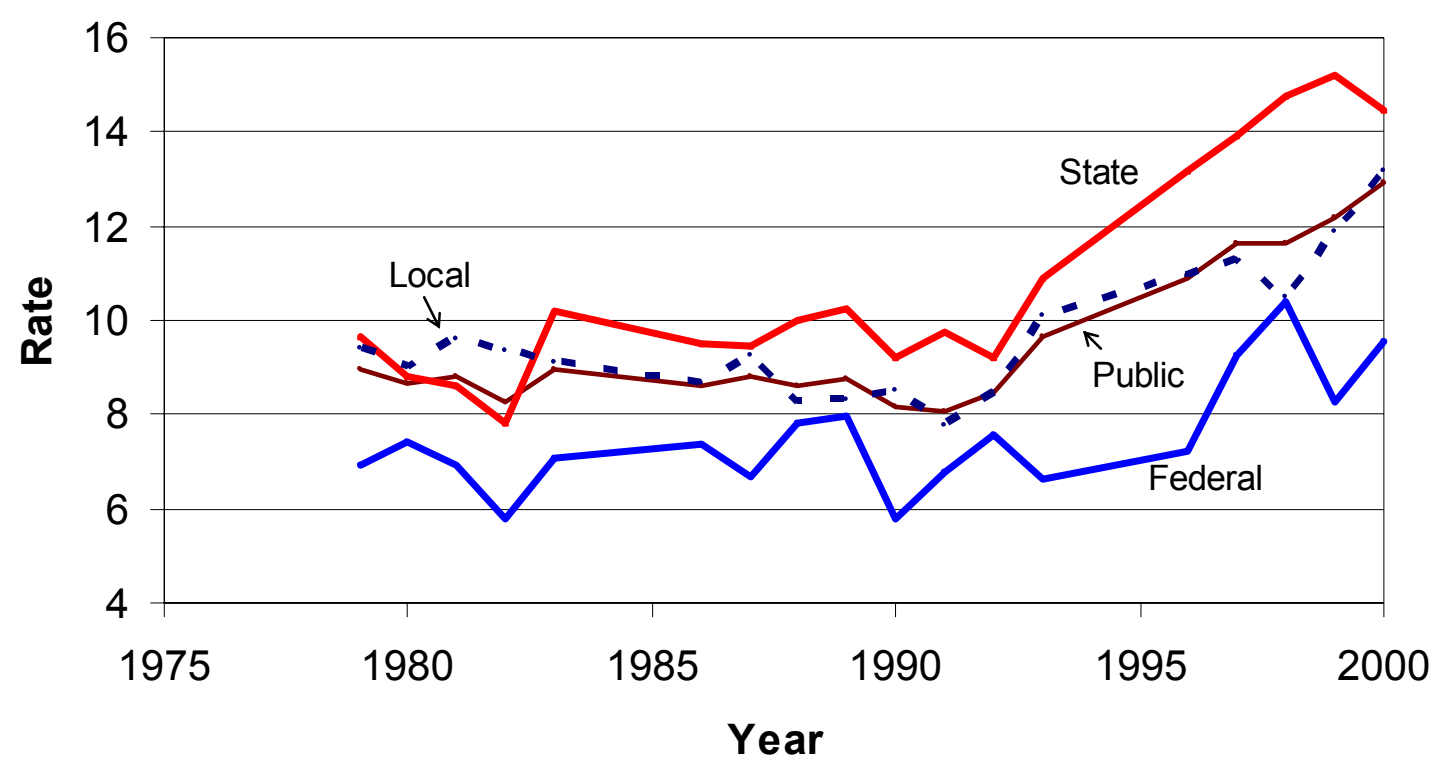

Entry rate into the public sector

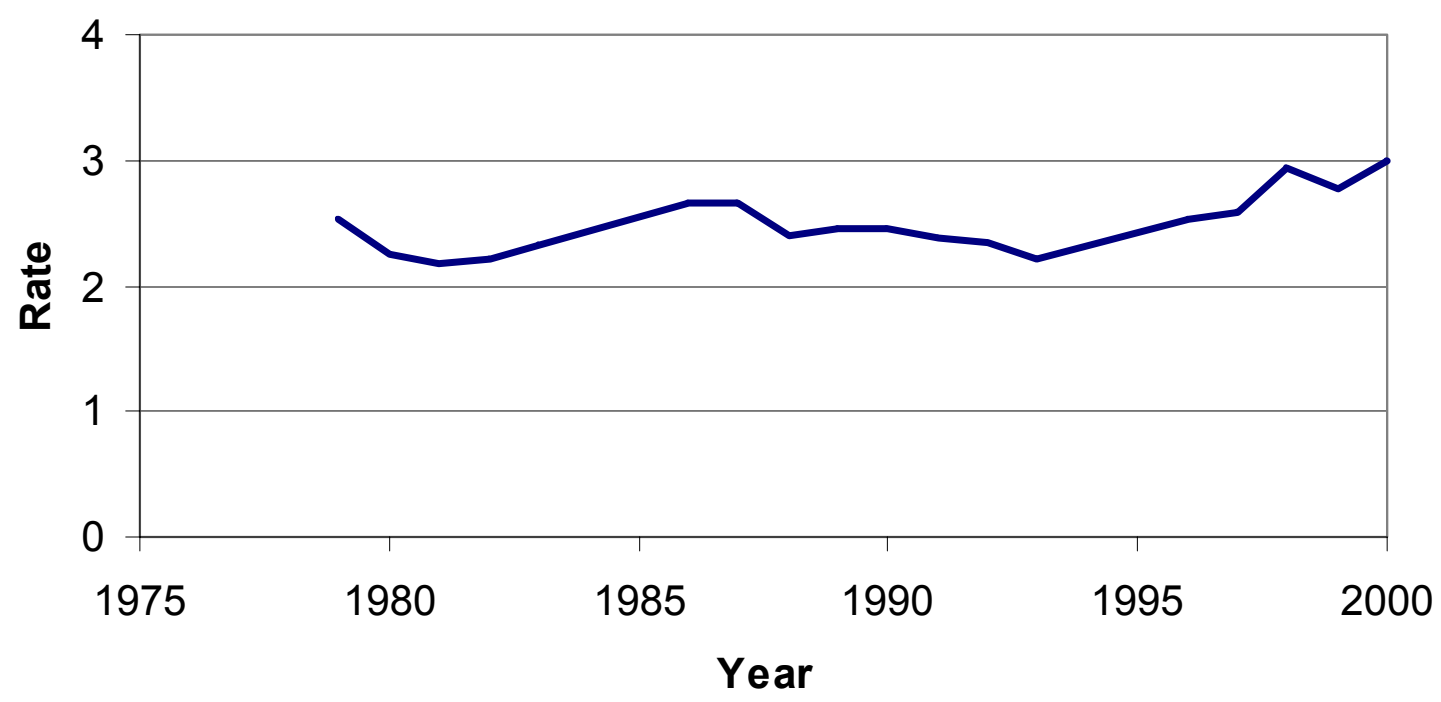


Figure 12

\section{Relative quit rates of high-skill workers}

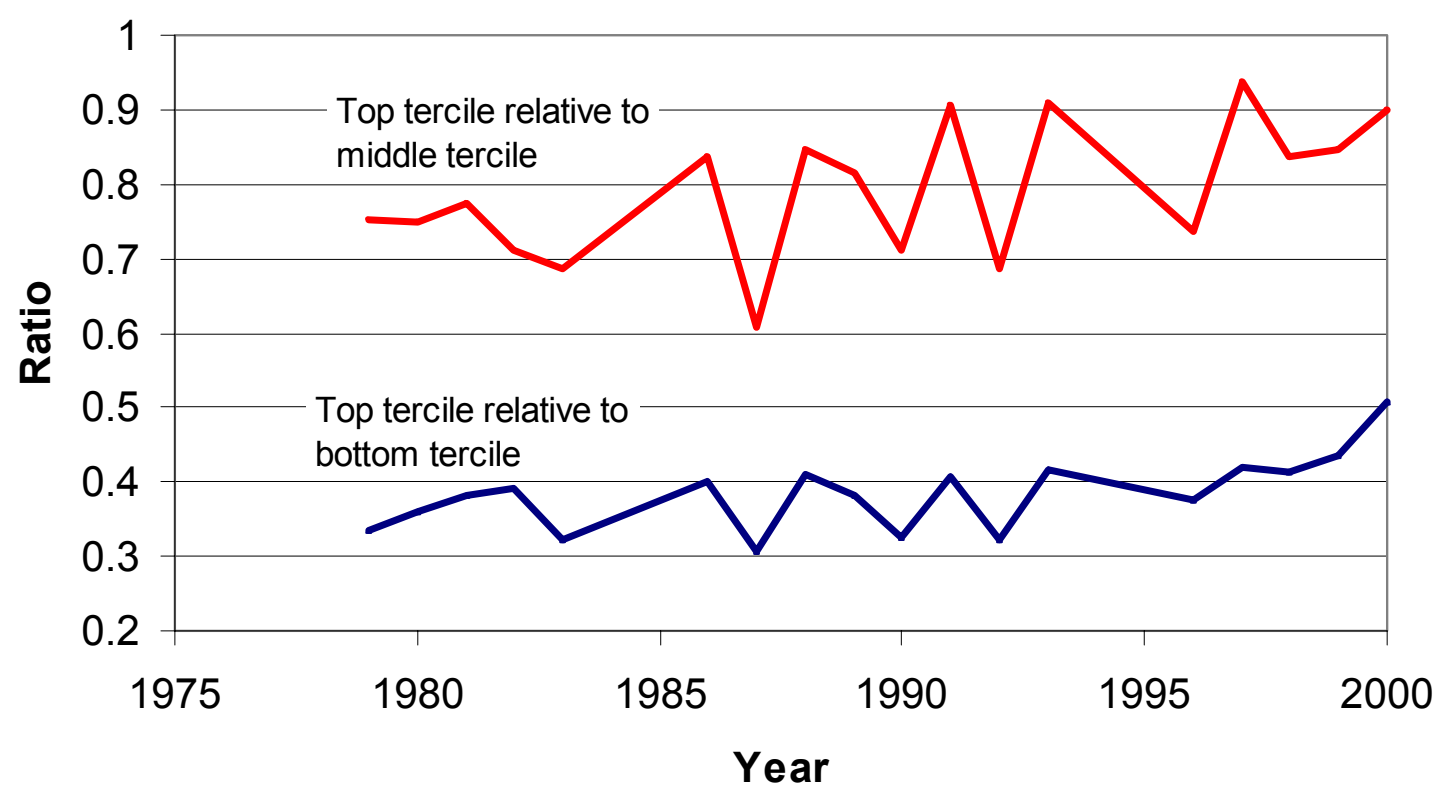




\section{Table 1. Education distributions in public and private sectors} (All workers)

$\begin{array}{ccccc}\text { Sector / Year } & \begin{array}{c}\text { High school } \\ \text { dropout }\end{array} & \begin{array}{c}\text { High school } \\ \text { graduate }\end{array} & \begin{array}{c}\text { Some } \\ \text { college }\end{array} & \begin{array}{c}\text { College graduate } \\ \text { or more }\end{array} \\ \begin{array}{c}\text { Public sector } \\ 1960\end{array} & 33.7 & 29.8 & 13.1 & 23.4 \\ 1970 & 23.9 & 34.7 & 14.0 & 27.4 \\ 1976-1980 & 11.0 & 32.0 & 16.8 & 40.3 \\ 1981-1985 & 8.1 & 31.6 & 18.0 & 42.3 \\ 1986-1990 & 5.7 & 31.5 & 20.4 & 42.4 \\ 1991-1995 & 3.7 & 25.5 & 27.9 & 43.0 \\ 1996-2000 & 3.1 & 23.3 & 27.9 & 45.8 \\ \text { Private sector } & & & & \\ 1960 & & & & 7.9 \\ 1970 & 50.3 & 31.7 & 10.2 & 9.9 \\ 1976-1980 & 37.9 & 39.5 & 12.8 & 15.4 \\ 1981-1985 & 21.7 & 44.9 & 18.0 & 21.9 \\ 1986-1990 & 16.3 & 44.4 & 19.6 & 23.7 \\ 1991-1995 & 14.1 & 43.2 & 20.9 & 25.4 \\ 1996-2000 & 11.5 & 36.9 & 28.0 & \end{array}$

Notes: The statistics for 1960 and 1970 are calculated using Census data. The statistics for all other periods are calculated by pooling the available CPS March Supplement data for the relevant years. 
Table 2. Year-to-year transition rates

End in:

Begin in:

Private sector

Public sector

Federal

State

Local

\begin{tabular}{cccccc}
\multicolumn{5}{c}{ End in: } \\
\cline { 1 - 5 } Private sector & & \multicolumn{4}{c}{ Public sector } \\
\cline { 1 - 3 } \cline { 3 - 6 } 97.5 & & All & Federal & State & Local \\
9.7 & 2.5 & 0.4 & 0.7 & 1.4 \\
7.6 & 90.3 & --- & --- & -- \\
11.2 & --- & 88.9 & 1.6 & 1.9 \\
9.7 & --- & 1.2 & 78.3 & 9.3 \\
& --- & 0.7 & 4.7 & 85.0
\end{tabular}


Table 3. Relative wage compression in the public sector and the sorting of workers

\begin{tabular}{|c|c|c|c|}
\hline \multirow[b]{2}{*}{ Dependent variable } & \multicolumn{3}{|c|}{ Ion model } \\
\hline & (1) & (2) & (3) \\
\hline \multirow[t]{2}{*}{ Log weekly wage } &.$- \overline{414}$ & -.289 & -.154 \\
\hline & $(.126)$ & $(.104)$ & $(.117)$ \\
\hline \multirow[t]{2}{*}{ Worker is in the top tenth of wage distribution } & -.204 & -.190 & -.153 \\
\hline & $(.048)$ & $(.047)$ & $(.045)$ \\
\hline \multirow[t]{2}{*}{ Worker is in the top third of wage distribution } & -.311 & -.266 & -.169 \\
\hline & $(.097)$ & $(.095)$ & $(.093)$ \\
\hline Controls for socioeconomic characteristics & No & Yes & Yes \\
\hline Controls for period effects & No & No & Yes \\
\hline \multicolumn{4}{|c|}{$\begin{array}{l}\text { Notes: Standard errors reported in parentheses. The regressions have } 34,454 \text { observations. All regression } \\
\text { specifications include dummy variables indicating if the worker is in-transit from the federal or state governments, } \\
\text { and a variable measuring the adjusted pay gap between the public and private sector. The socioeconomic } \\
\text { characteristics held constant in column } 3 \text { include a vector of variables indicating the worker's age, educational } \\
\text { attainment, region of residence, and a dummy variable indicating if the worker's race and gender. }\end{array}$} \\
\hline
\end{tabular}




\title{
Table 4. The wage structure and the sorting of workers, by level of government
}

\author{
$\underline{\text { Sector / Dependent variable }}$ \\ Federal Government \\ Log weekly wage \\ $-.069$ \\ $-.090$ \\ .031 \\ $(.307)$ \\ (.304) \\ Worker is in the top third of wage distribution \\ $-.181$ \\ $-.251$ \\ $-.107$ \\ $(.162)$ \\ $(.182)$ \\ State Government \\ Log weekly wage \\ $-.835$ \\ $-.510$ \\ $-.135$ \\ $(.365)$ \\ $(.379)$ \\ Worker is in the top third of wage distribution \\ $-.467$ \\ $-.552$ \\ $-.336$ \\ $(.237)$ \\ (.249) \\ Local Government \\ Log weekly wage \\ $-.131$ \\ $-.063$ \\ .014 \\ (.129) \\ (.109) \\ Worker is in the top third of wage distribution \\ $-.104$ \\ $-.082$ \\ $-.100$ \\ $(.090)$ \\ $(.088)$ \\ $(.084)$ \\ Controls for period effects \\ Controls for socioeconomic characteristics

$\begin{array}{lll}\text { No } & \text { Yes } & \text { Yes } \\ \text { No } & \text { No } & \text { Yes }\end{array}$ \\ Notes: Standard errors reported in parentheses. There are 5,480 observations in the regressions for the federal \\ government, 9,972 observations in the regressions for the state government, and 19,002 in the regressions for the \\ local government. All regression specifications include a variable measuring the adjusted pay gap between the \\ particular government sector and the private sector. The socioeconomic characteristics held constant in column 3 \\ include a vector of variables indicating the worker's age, educational attainment, region of residence, and a dummy \\ variable indicating if the worker's race and gender.
}

